\title{
Green Solvents as a promising approach to degradation of organophosphorate Pesticides.
}

\author{
Paulina Pavez,* Guillermo Oliva and Daniela Millán \\ Facultad de Química. Pontificia Universidad Católica de Chile. Casilla 306, Santiago 6094411, \\ Chile.
}

\begin{abstract}
Author Information
*Corresponding authors. Tel.: +56-02-23541743; fax: +56-02-26864744; e-mail: ppavezg@uc.cl
\end{abstract}

Present address: Facultad de Química, Pontificia Universidad Católica de Chile, Av. Vicuña Mackenna 4860, Santiago 6094411, Chile. 


\section{Supporting information}

\begin{tabular}{|c|c|}
\hline Table of contents & \\
\hline $\begin{array}{l}\text { Experimental section: Kinetic measurements, Gas chromatography-mass spectrometry } \\
(G C / M S) \text { and Electrospray ionization mass spectrometry (ESI-MS) }\end{array}$ & S4 \\
\hline $\begin{array}{l}\left.\text { Figure S1: }{ }^{31} \mathrm{P}-\mathrm{NMR} \text { spectrum }(400 \mathrm{MHz}) \text { of compound } 3 \text { (scheme } 4\right) \text {, obtained in } \\
\text { the reaction of } 0,0 \text {-diethyl chlorophosphate with piperidine in } 2-\mathrm{MeTHF} \text { at } 25^{\circ} \mathrm{C} \text {. }\end{array}$ & S5 \\
\hline $\begin{array}{l}\left.\text { Figure S2: }{ }^{31} \mathrm{P}-\mathrm{NMR} \text { spectrum }(400 \mathrm{MHz}) \text { of compound } 4 \text { (scheme } 4\right) \text {, obtained in } \\
\text { the reaction of } 0,0 \text {-diethyl chlorophosphate with } \mathrm{NaOH} \text { in } 2-\mathrm{MeTHF} \text { at } 25^{\circ} \mathrm{C} \text {. }\end{array}$ & S5 \\
\hline $\begin{array}{l}\text { Figure S3: GC-MS chromatogramme and mass spectrum of compound 3B from the } \\
\text { reaction of } 2 \text { with piperidine in } \mathrm{EL} \text { at } 25^{\circ} \mathrm{C} \text {. }\end{array}$ & S6 \\
\hline $\begin{array}{l}\text { Table S1: Pseudo-first-order rate constants }\left(k_{\mathrm{obsd}}\right) \text { for the reaction of } 1 \text { with } \\
\text { piperidine in different solvents at the same amine concentration }(0.2 \mathrm{M}) \text { at } 25^{\circ} \mathrm{C} .{ }^{a}\end{array}$ & S7 \\
\hline $\begin{array}{l}\text { Table S2: Pseudo-first-order rate constants }\left(k_{\text {obsd }}\right) \text { for the reaction of } 2 \text { with } \\
\text { piperidine in different solvents at the same amine concentration }(2.8 \mathrm{M}) \text { at } 25^{\circ} \mathrm{C} .{ }^{a}\end{array}$ & $\mathrm{~S} 8$ \\
\hline $\begin{array}{l}\text { Figure S4 : }{ }^{31} \mathrm{P}-\mathrm{NMR} \text { spectrum of the product formed in the reaction of } 1 \text { with } \\
\text { piperidine in }[\mathrm{Bmim}] \mathrm{BF}_{4} \text { at } 25^{\circ} \mathrm{C}\end{array}$ & S9 \\
\hline $\begin{array}{l}\text { Figure S5: }{ }^{31} \mathrm{P}-\mathrm{NMR} \text { spectrum of the product formed in the reaction of } 1 \text { with } \\
\text { piperidine in }[\mathrm{Bmim}] \mathrm{PF}_{6} \text { at } 25^{\circ} \mathrm{C} \text {. }\end{array}$ & S9 \\
\hline $\begin{array}{l}\text { Figure S6: }{ }^{31} \mathrm{P}-\mathrm{NMR} \text { spectrum of the product formed in for the reaction of } \mathbf{1} \text { with } \\
\text { piperidine in }[\mathrm{Bmim}] \mathrm{NTf}_{2} \text { at } 25^{\circ} \mathrm{C} \text {. }\end{array}$ & S10 \\
\hline $\begin{array}{l}\text { Figure S7: }{ }^{31} \mathrm{P}-\mathrm{NMR} \text { spectrum of the product formed in for the reaction of } \mathbf{1} \text { with } \\
\text { piperidine in }[\mathrm{Bmim}] \mathrm{DCA} \text { at } 25^{\circ} \mathrm{C} \text {. }\end{array}$ & $\mathrm{S} 10$ \\
\hline $\begin{array}{l}\text { Figure S8: }{ }^{3 \mathrm{I}} \mathrm{P}-\mathrm{NMR} \text { spectrum of the product formed in for the reaction of } \mathbf{1} \text { with } \\
\text { piperidine in }[\mathrm{Bmim}] \mathrm{OTf} \text { at } 25^{\circ} \mathrm{C} \text {. }\end{array}$ & S11 \\
\hline $\begin{array}{l}\text { Figure S9: }{ }^{31} \mathrm{P}-\mathrm{NMR} \text { spectrum of the product formed in for the reaction of } 1 \text { with } \\
\text { piperidine in }[\mathrm{Bmpyrr}] \mathrm{DCA} \text { at } 25^{\circ} \mathrm{C} \text {. }\end{array}$ & S11 \\
\hline $\begin{array}{l}\text { Figure S10: }{ }^{31} \mathrm{P}-\mathrm{NMR} \text { spectrum of the product formed in for the reaction of } 1 \text { with } \\
\text { piperidine in }[\mathrm{Bmpyrr}]\left[\mathrm{Tf}_{2} \mathrm{~N}\right] \text { at } 25^{\circ} \mathrm{C} \text {. }\end{array}$ & S12 \\
\hline $\begin{array}{l}\text { Figure S11: }{ }^{31} \mathrm{P}-\mathrm{NMR} \text { spectrum of the product formed in for the reaction of } 1 \text { with } \\
\text { piperidine in }[\mathrm{Em} 2 \mathrm{pAm}]\left[\mathrm{Tf}_{2} \mathrm{~N}\right] \text { at } 25^{\circ} \mathrm{C} \text {. }\end{array}$ & $\mathrm{S} 12$ \\
\hline $\begin{array}{l}\text { Figure S12: }{ }^{31} \mathrm{P}-\mathrm{NMR} \text { spectrum of the product formed in for the reaction of } 1 \text { with } \\
\text { piperidine in }\left[\mathrm{B}_{2} \mathrm{mim}\right][\mathrm{OTf}] \text { at } 25^{\circ} \mathrm{C} \text {. }\end{array}$ & S13 \\
\hline $\begin{array}{l}\text { Figure S13: }{ }^{31} \mathrm{P}-\mathrm{NMR} \text { spectrum of the product formed in for the reaction of } \mathbf{1} \text { with } \\
\text { piperidine in }[\mathrm{Bmpyrr}][\mathrm{OTf}] \text { at } 25^{\circ} \mathrm{C} \text {. }\end{array}$ & $\mathrm{S} 13$ \\
\hline $\begin{array}{l}\text { Figure S14: }{ }^{31} \mathrm{P}-\mathrm{NMR} \text { spectrum of the product formed in for the reaction of } 1 \text { with } \\
\text { piperidine in }\left[\mathrm{B}_{2} \mathrm{mim}\right]\left[\mathrm{Tf}_{2} \mathrm{~N}\right] \text { at } 25^{\circ} \mathrm{C} \text {. }\end{array}$ & $\mathrm{S} 14$ \\
\hline $\begin{array}{l}\text { Figure S15: }{ }^{31} \mathrm{P}-\mathrm{NMR} \text { spectrum of the product formed in for the reaction of } 1 \text { with } \\
\text { piperidine in }\left[\mathrm{B}_{2} \mathrm{mim}\right]\left[\mathrm{BF}_{4}\right] \text { at } 25^{\circ} \mathrm{C} \text {. }\end{array}$ & $\mathrm{S} 14$ \\
\hline $\begin{array}{l}\text { Figure S16: Stacked }{ }^{31} \mathrm{P}-\mathrm{NMR} \text { plot for the reaction of } 1 \text { with piperidine in } 2-\mathrm{MeTHF} \\
\text { at } 25^{\circ} \mathrm{C} \text {. }\end{array}$ & $\mathrm{S} 15$ \\
\hline $\begin{array}{l}\text { Figure S17: Stacked }{ }^{31} \mathrm{P}-\mathrm{NMR} \text { plot for the reaction of } 1 \text { with piperidine in Cymene } \\
\text { at } 25^{\circ} \mathrm{C} \text {. }\end{array}$ & $\mathrm{S} 15$ \\
\hline Figure S18: Stacked ${ }^{31} \mathrm{P}-\mathrm{NMR}$ plot for the reaction of 1 witl & S16 \\
\hline
\end{tabular}




\begin{tabular}{|c|c|}
\hline at $25^{\circ} \mathrm{C}$. & \\
\hline $\begin{array}{l}\text { Figure S19: Stacked }{ }^{31} \mathrm{P}-\mathrm{NMR} \text { plot for the reaction of } 1 \text { with piperidine in } \\
\text { Lymonene at } 25^{\circ} \mathrm{C} \text {. }\end{array}$ & S16 \\
\hline $\begin{array}{l}\text { Figure S20: Stacked }{ }^{31} \mathrm{P}-\mathrm{NMR} \text { plot for the reaction of } 1 \text { with piperidine in } \mathrm{PC} \text { at } \\
25^{\circ} \mathrm{C} \text {. }\end{array}$ & S17 \\
\hline $\begin{array}{l}\text { Figure S21: Stacked }{ }^{31} \mathrm{P}-\mathrm{NMR} \text { plot for the reaction of } 1 \text { with piperidine in } \mathrm{MeCN} \text { at } \\
25^{\circ} \mathrm{C} \text {. }\end{array}$ & S17 \\
\hline $\begin{array}{l}\text { Figure S22: Stacked }{ }^{31} \mathrm{P}-\mathrm{NMR} \text { plot for the reaction of } 1 \text { with piperidine in dioxane at } \\
25^{\circ} \mathrm{C} \text {. }\end{array}$ & $\mathrm{S} 18$ \\
\hline $\begin{array}{l}\text { Figure S23: Stacked }{ }^{3 \mathrm{l}} \mathrm{P}-\mathrm{NMR} \text { plot for the reaction of } 1 \text { with piperidine in DMSO at } \\
25^{\circ} \mathrm{C} \text {. }\end{array}$ & S18 \\
\hline $\begin{array}{l}\text { Table S3. Viscosity, Kamlet-Taft descriptors and first-order rate constants }\left(k_{\text {obsd }}\right) \text { for } \\
\text { degradation of } \mathbf{1} \text { and } \mathbf{2} \text { with piperidine. }\end{array}$ & S19 \\
\hline $\begin{array}{l}\text { Figure S24. Progressive }{ }^{31} \mathrm{P} \text { NMR spectra obtained for degradation of } 2 \text { with } \\
\text { piperidine }(2.8 \mathrm{M}) \text { at } 25^{\circ} \mathrm{C} \text { in } 2-\mathrm{MeTHF}\end{array}$ & $\mathrm{S} 20$ \\
\hline $\begin{array}{l}\text { Figure S25. Progressive }{ }^{31} \mathrm{P} \text { NMR spectra obtained for degradation of } 2 \text { with } \\
\text { piperidine }(2.8 \mathrm{M}) \text { at } 25^{\circ} \mathrm{C} \text { in GLU. }\end{array}$ & $\mathrm{S} 20$ \\
\hline $\begin{array}{l}\text { Figure S26: Stacked }{ }^{31} \mathrm{P}-\mathrm{NMR} \text { plot for the reaction of } 2 \text { with piperidine in Cymene } \\
\text { at } 25^{\circ} \mathrm{C} \text {. }\end{array}$ & $\mathrm{S} 21$ \\
\hline $\begin{array}{l}\text { Figure S27: Stacked }{ }^{3 \mathrm{l}} \mathrm{P}-\mathrm{NMR} \text { plot for the reaction of } \mathbf{2} \text { with piperidine in } \\
\text { Lymonene at } 25^{\circ} \mathrm{C} \text {. }\end{array}$ & S21 \\
\hline $\begin{array}{l}\text { Figure S28: (A) }{ }^{1} \text { H NMR spectra (aromatic region) for degradation of } 2 \text { with } \\
\text { piperidine in EL. (B) After addition of 4-nitrophenol. }\end{array}$ & S22 \\
\hline $\begin{array}{l}\text { Figure S29: Experimental plot of absorbance } v s \text { wavelength for the reaction of } \\
\text { piperidine }(2.8 \mathrm{M}) \text { with } 2 \text { in EL at } 25^{\circ} \mathrm{C} \text {. }\end{array}$ & S22 \\
\hline $\begin{array}{l}\text { Figure S30: ESI-MS/MS(-) of the compound } 4 \text { of } m / z 152.9 \text {, from a reaction of } 2 \\
\text { with piperidine in EL }\end{array}$ & $\mathrm{S} 23$ \\
\hline $\begin{array}{l}\text { Figure S31: ESI-MS/MS(-) of the compound } 5 \text { of } \mathrm{m} / z \text { 246.0, from a reaction of } 2 \\
\text { with piperidine in EL }\end{array}$ & $\mathrm{S} 23$ \\
\hline Figure S32: Structure of (a) Ethyl Lactate and (b) Ethyl Propionate & $\mathrm{S} 24$ \\
\hline $\begin{array}{l}\text { Figure S33: Progressive }{ }^{31} \mathrm{P} \text { NMR spectra obtained for the reaction of } 2 \text { with } \\
\text { piperidine in Ethyl Propianate }(\mathrm{EP}) \text {. }\end{array}$ & $\mathrm{S} 24$ \\
\hline $\begin{array}{l}\text { Table S4: Pseudo-first-order rate constants }\left(k_{\text {obsd }}\right) \text { for the degradation routes of } 2 \text { in } \\
\text { several solvents. }\end{array}$ & $\mathrm{S} 25$ \\
\hline $\begin{array}{l}\text { Figure S34: ESI-MS/MS(-) of the compound } 5 \text { of } m / z 100.1 \text {, from a reaction of } 1 \\
\text { with piperidine in } \mathrm{MeCN}\end{array}$ & S26 \\
\hline
\end{tabular}




\section{Experimental section:}

Kinetic measurements. In a typical spectrophotometric measurement a quartz cuvette (light-path $0.2 \mathrm{~cm}$ ) containing $500 \mu \mathrm{L}$ of solvent (COS, ILs or bio-based solvents) was thermostated at $25^{\circ} \mathrm{C}$ during 10 minutes. Then, $5 \mu \mathrm{L}$ of $\mathbf{1}(0,1 \mathrm{M}$ in $\mathrm{MeCN})$ and pure piperidine were added to each cuvette $(20 \mu \mathrm{L})$. The spectra were recorded at different reaction times and pseudo-first-order rate coefficients $\left(k_{\text {obsd }}\right)$ were found for all reactions. These were obtained by means of the kinetic software of the spectrophotometer, at the wavelength where the greatest absorbance change was observed.

Typical ${ }^{31} \mathrm{P}$ NMR experiment for pesticide 1: a NMR tube containing $500 \mu \mathrm{L}$ of solvent (COS, ILs or bio-based solevnts) was thermostated at $25^{\circ} \mathrm{C}$ during 10 minutes. Then $10 \mu \mathrm{L}$ of pesticide 1 $(0.5 \mathrm{M}$ in $\mathrm{MeCN})$ and $22 \mu \mathrm{L}$ of neat piperidine were added. For experiments with pesticide 2 , the same amounts of solvent and pesticide were used, but $200 \mu \mathrm{L}$ of neat piperidine was used. In both cases capillars of deuterated $\mathrm{MeCN}$ were used as solvent reference. It is noteworthy that in the degradation of 2 , we use $200 \mu \mathrm{L}$ of neat piperidine, in order to increase the reaction times, but the same reactivity or products distribucion was obtained when we used $22 \mu \mathrm{L}$ of neat piperidine.

The spectra were recorded at different reaction times and pseudo-first-order rate coefficients $\left(k_{\text {obsd }}\right)$ were found for the different reaction routes $\left(\mathrm{S}_{\mathrm{N}} \mathrm{Ar}, \mathrm{S}_{\mathrm{N}} 2(\mathrm{P})\right.$ and $\left.\mathrm{S}_{\mathrm{N}} 2(\mathrm{C})\right)$. The overall $k_{\text {obsd }}$ values obtained for degradation of $\mathbf{2}$ were obtained by integration of the NMR signals for $\mathbf{2}$ and plotting $\log$ (integration) vs time. To obtain the rate constants for the products formation, we multiplied

$k_{\text {obsd }}$ by the fraction of each product relative to the total products. The molar concentrations of the products at the end of the reactions were obtained by quantitative analysis of each product.

Gas chromatography-mass spectrometry (GC/MS). GC/MS analysis was performed using a gas chromatograph fitted with a split-splitless injector and a Elite-5MS column $(30 \mathrm{~m} \times 0.25 \mathrm{~mm}$ i.d., $0.25 \mu \mathrm{md}$.f). Helium was used as a carrier gas at a flow rate of $1.0 \mathrm{~mL} / \mathrm{min}$. The injection port was maintained at $70.0^{\circ} \mathrm{C}$, and the split ratio was 50:1. Oven temperature was programed from $50^{\circ} \mathrm{C}$ for $3 \mathrm{~min}$, then ramp $1: 5^{\circ} \mathrm{C} / \mathrm{min}$ to $250^{\circ} \mathrm{C}$ hold for $15 \mathrm{~min}$. Ionization mode was electron impact ionization and the scanning range was from $45 \mathrm{amu}$ to $500 \mathrm{amu}$. Mass spectra were obtained at $0.35 \mathrm{~s}$ intervals.

Electrospray ionization mass spectrometry (ESI-MS). ESI and the QqQ (linear trap) mass spectrometer were operated in the negative-ion mode using the multiple reaction monitoring (MRM) scan type. Main conditions: curtain gas nitrogen flow $=10 \mathrm{~mL} \mathrm{~min}^{-1}$; ion spray voltage $=-4500 \mathrm{eV}$; declustering potential $=-60 \mathrm{eV}$; entrance potential $=-10 \mathrm{eV}$; collision cell exit potential $=-12 \mathrm{eV}$; source temperature was set at $300{ }^{\circ} \mathrm{C}$ and source gas GS1 and GS2 were set to 12 and 0, respectively. All data were acquired using Analyst 1.6.2 (AB Sciex). 


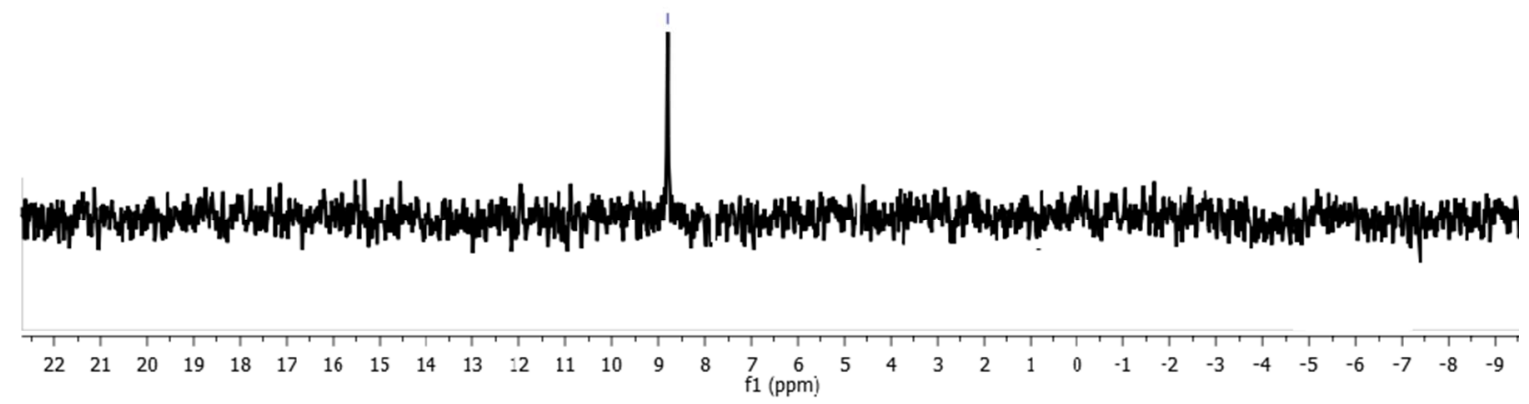

Figure S1: ${ }^{31} \mathrm{P}-\mathrm{NMR}$ spectrum $(400 \mathrm{MHz})$ of compound 3 (scheme 4), obtained in the reaction of 0,0 -diethyl chlorophosphate with piperidine in $2-\mathrm{MeTHF}$ at $25^{\circ} \mathrm{C}$.

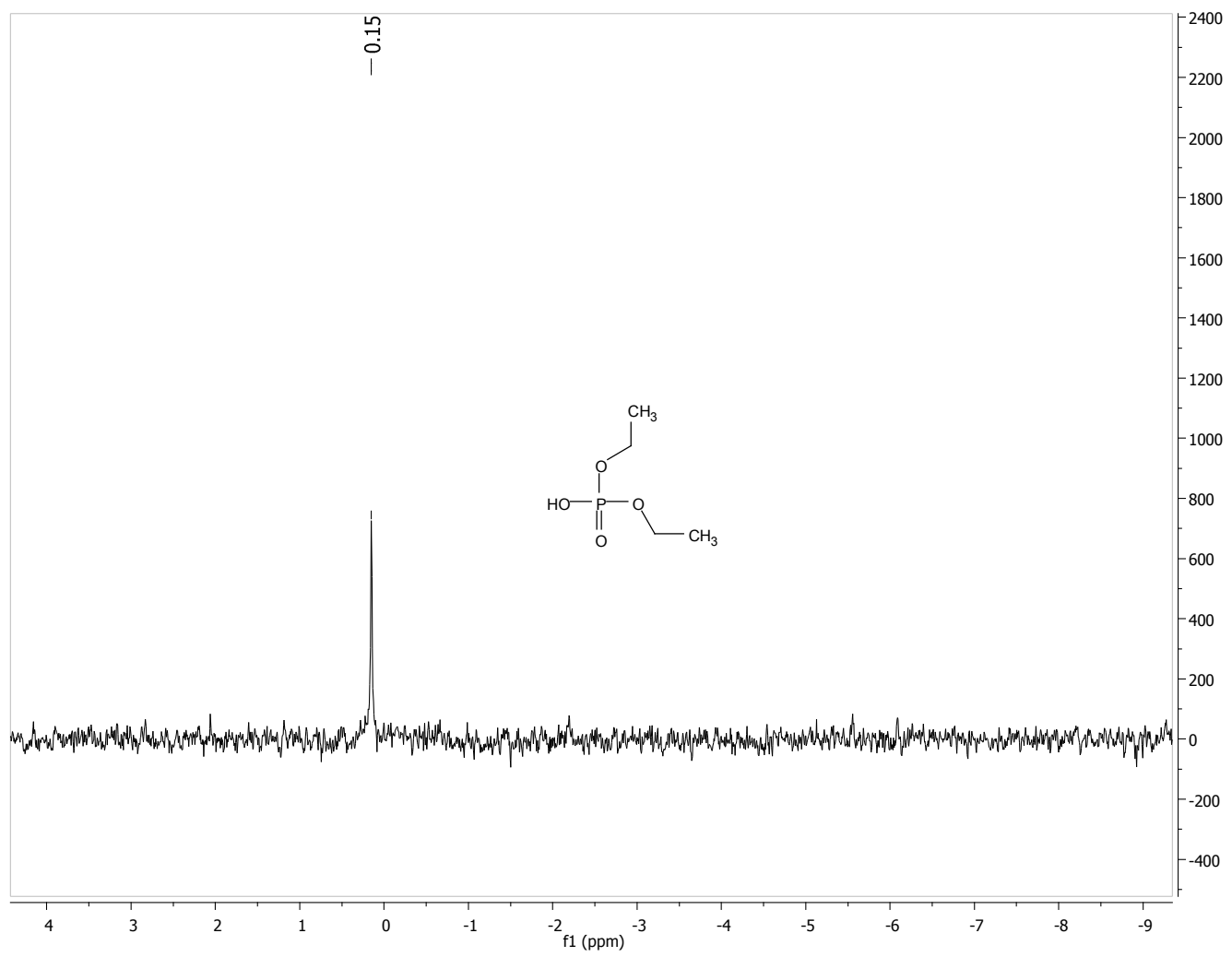

Figure S2: ${ }^{31} \mathrm{P}-\mathrm{NMR}$ spectrum $(400 \mathrm{MHz})$ of compound 4 (scheme 4$)$, obtained in the reaction of 0,0 -diethyl chlorophosphate with $\mathrm{NaOH}$ in $2-\mathrm{MeTHF}$ at $25^{\circ} \mathrm{C}$. 


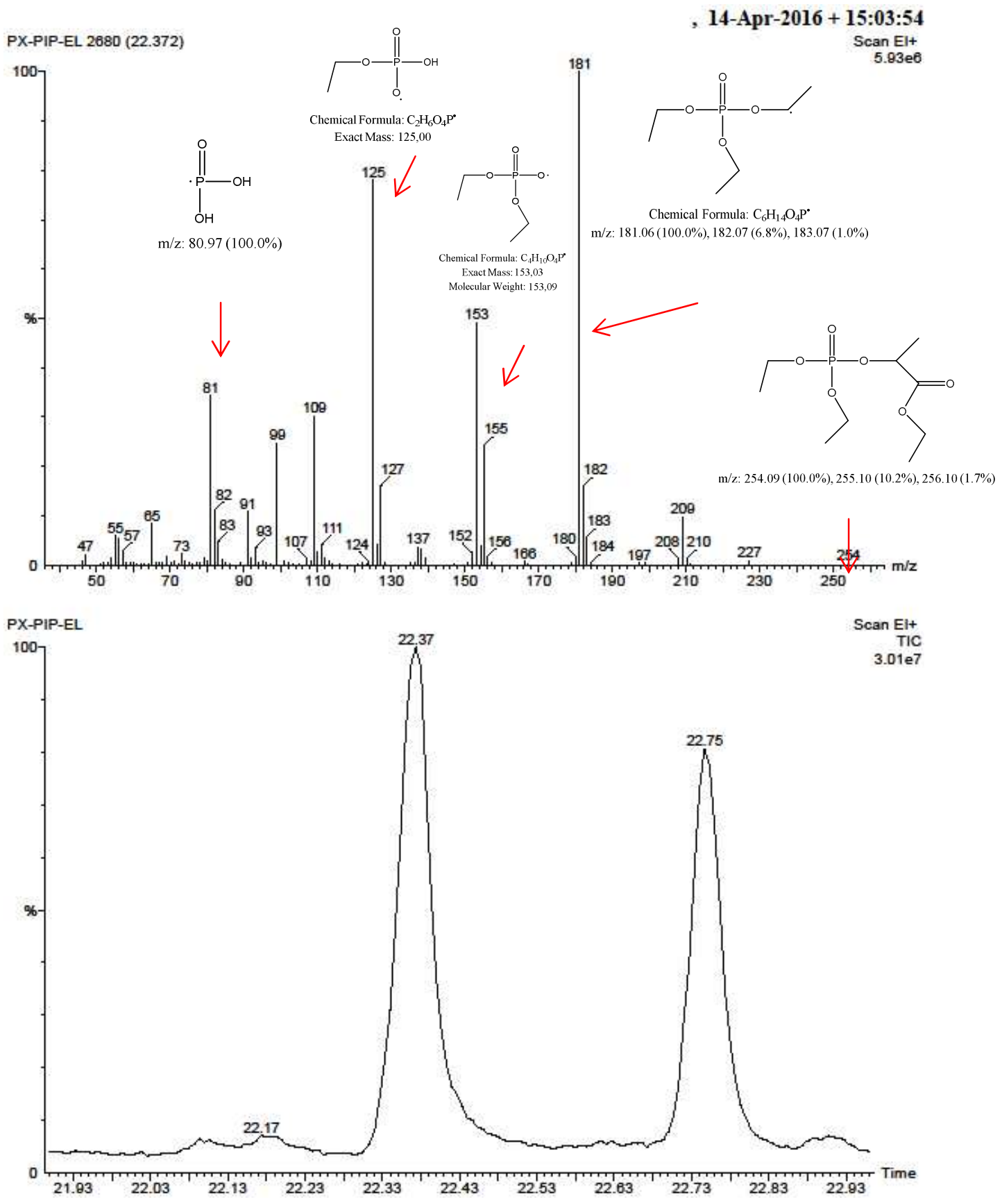

Figure S3: GC-MS chromatogramme and mass spectrum of compound 3B from the reaction of 2 with piperidine in $\mathrm{EL}$ at $25^{\circ} \mathrm{C}$. 
Table S1: Pseudo-first-order rate constants ( $\left.k_{\mathrm{obsd}}\right)$ for the reaction of 1 with piperidine in different solvents at the same amine concentration $(0.2 \mathrm{M})$ at $25^{\circ} \mathrm{C} .^{a}$

\begin{tabular}{|c|c|c|c|}
\hline Solvent & $10^{5} k_{\text {obsd }} / s^{-1}$ & Solvent & $10^{5} k_{\text {obsd }} / \mathrm{s}^{-1}$ \\
\hline CYM & 6.45 & {$\left[\mathrm{Em}_{2} \mathrm{pAm}\right] \mathrm{NTf}_{2}$} & 150 \\
\hline LYM & 3.23 & {$\left[\mathrm{~B}_{2} \mathrm{mim}\right] \mathrm{BF}_{4}$} & 230 \\
\hline Me-THF & 15.4 & [Bmpyrr]DCA & 342 \\
\hline $\mathrm{PC}$ & 166 & [Bmpyrr]NTf 2 & 128 \\
\hline$\left[\mathrm{B}_{2} \mathrm{mim}\right] \mathrm{OTf}$ & 263 & [Bmpyrr]OTf & 205 \\
\hline$[\mathrm{Bmim}] \mathrm{BF}_{4}$ & 185 & {$\left[\mathrm{Bm}_{2} \mathrm{im}\right] \mathrm{NTf}_{2}$} & 140 \\
\hline$[\mathrm{Bmim}] \mathrm{PF}_{6}$ & 144 & $\mathrm{H}_{2} \mathrm{O} \mathrm{pH}=\mathrm{p} K_{\mathrm{a}}$ & 3.0 \\
\hline$[\mathrm{Bmim}] \mathrm{DCA}$ & 247 & DMSO & 230 \\
\hline$[\mathrm{Bmim}] \mathrm{NTf}_{2}$ & 110 & $\mathrm{MeCN}$ & 71 \\
\hline [Bmim]OTf & 175 & Dioxane & 28 \\
\hline
\end{tabular}

${ }^{a}$ results are the average of three measurements. 
Table S2: Pseudo-first-order rate constants $\left(k_{\text {obsd }}\right)$ for the reaction of 2 with piperidine in different solvents at the same amine concentration $(2.8 \mathrm{M})$ at $25^{\circ} \mathrm{C} .^{a}$

\begin{tabular}{|c|c|c|c|}
\hline Solvent & $10^{5} k_{\text {obsd }} / \mathrm{s}^{-1}$ & Solvent & $10^{5} k_{\text {obsd }} / s^{-1}$ \\
\hline $\bar{~} \mathrm{CYM}$ & $\overline{566.0}$ & [Bmpyrr]DCA & 6.42 \\
\hline LYM & 145 & {$[\mathrm{Bmpy}] \mathrm{DCA}^{b}$} & 6.44 \\
\hline THF & 65.8 & {$\left[\right.$ Bmpyrr] $\mathrm{NTf}_{2}{ }^{b}$} & 2.72 \\
\hline GLU & 1490 & {$\left[\mathrm{~B}_{2} \mathrm{mim}\right] \mathrm{NTf}_{2}{ }^{b}$} & 4.95 \\
\hline$[\mathrm{Bmim}] \mathrm{BF}_{4}{ }^{b}$ & 12.0 & $\mathrm{H}_{2} \mathrm{O} \mathrm{pH}=\mathrm{p} K_{\mathrm{a}}^{c}$ & 18.8 \\
\hline$[\mathrm{Bmim}] \mathrm{PF}_{6}{ }^{b}$ & 8.43 & $\mathrm{MeCN}^{b}$ & 2.15 \\
\hline$[\mathrm{Bmim}] \mathrm{DCA}^{b}$ & 13.7 & Dioxane $^{b}$ & 0.64 \\
\hline$[\mathrm{Bmim}] \mathrm{NTf}_{2}{ }^{b}$ & 6.62 & & \\
\hline$\left[\mathrm{Em}_{2} \mathrm{pAm}\right] \mathrm{NTf}_{2}{ }^{b}$ & 3.35 & & \\
\hline$\left[\mathrm{B}_{2} \mathrm{mim}\right] \mathrm{BF}_{4}{ }^{b}$ & 4.83 & & \\
\hline
\end{tabular}

${ }^{a}$ results are the average of three measurements. ${ }^{b}$ see reference 17 


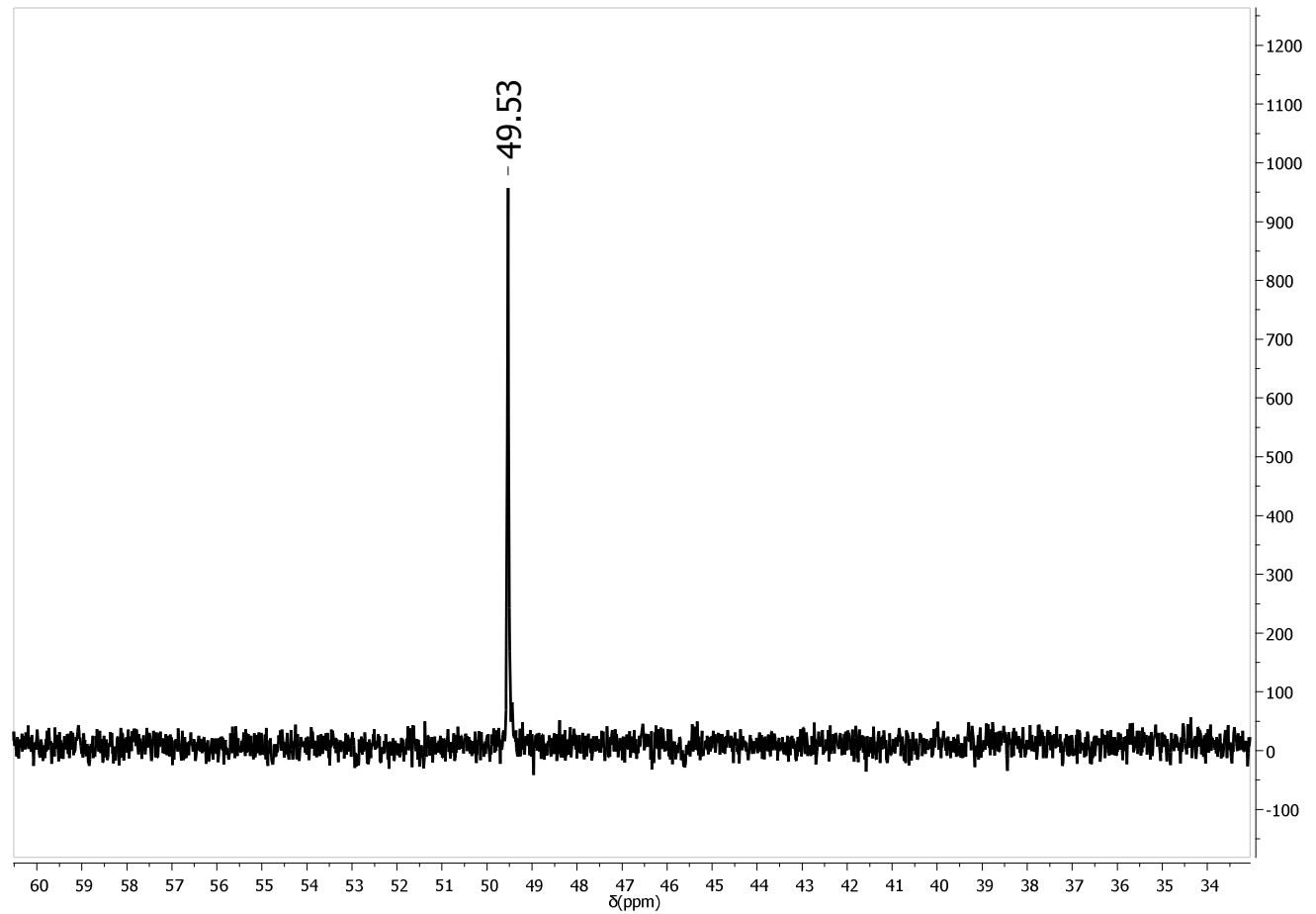

Figure S4 : ${ }^{31} \mathrm{P}-\mathrm{NMR}$ spectrum of the product formed in the reaction of $\mathbf{1}$ with piperidine in $[\mathrm{Bmim}] \mathrm{BF}_{4}$ at $25^{\circ} \mathrm{C}$.

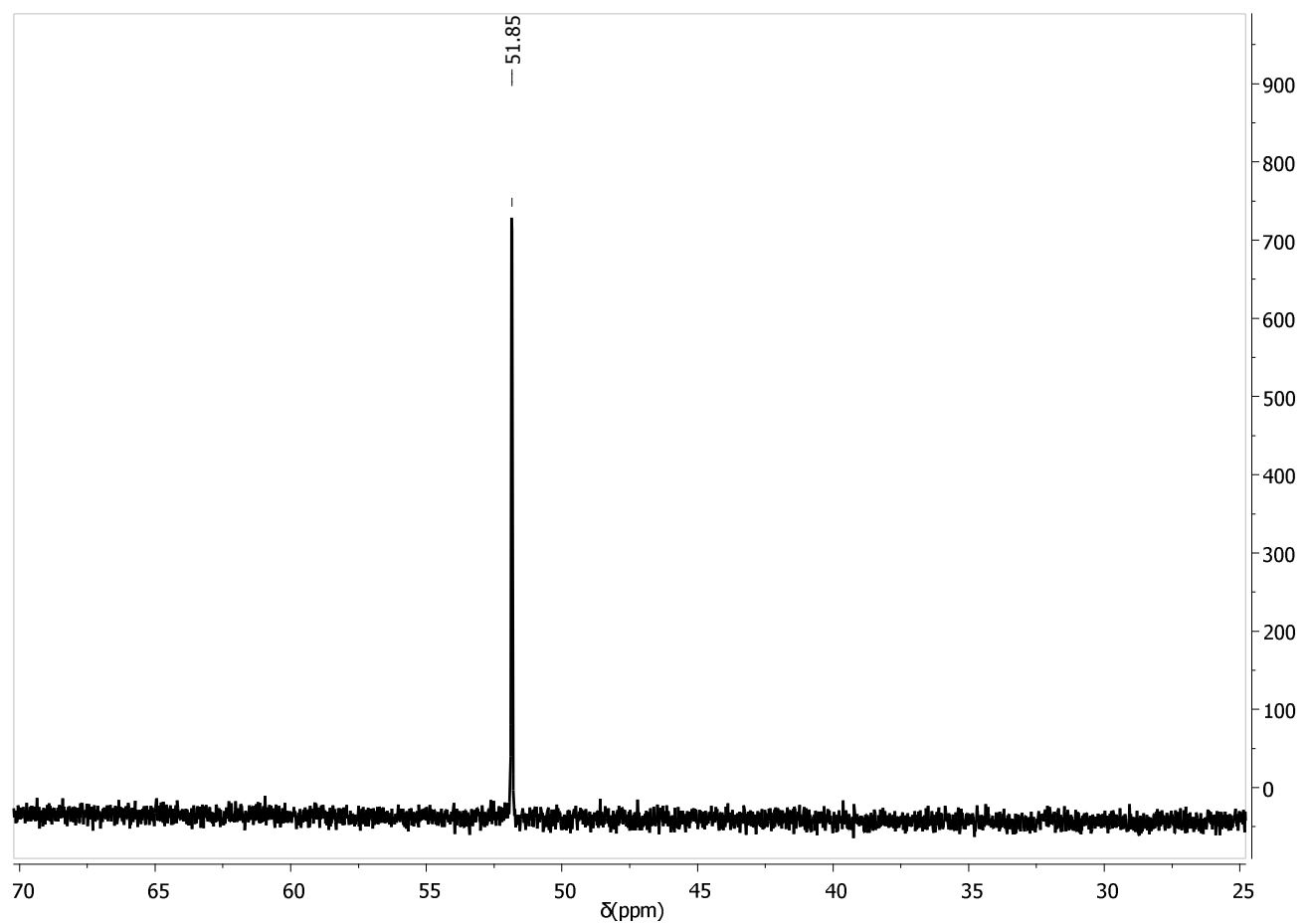

Figure S5: ${ }^{31} \mathrm{P}-\mathrm{NMR}$ spectrum of the product formed in the reaction of $\mathbf{1}$ with piperidine in $[\mathrm{Bmim}] \mathrm{PF}_{6}$ at $25^{\circ} \mathrm{C}$. 


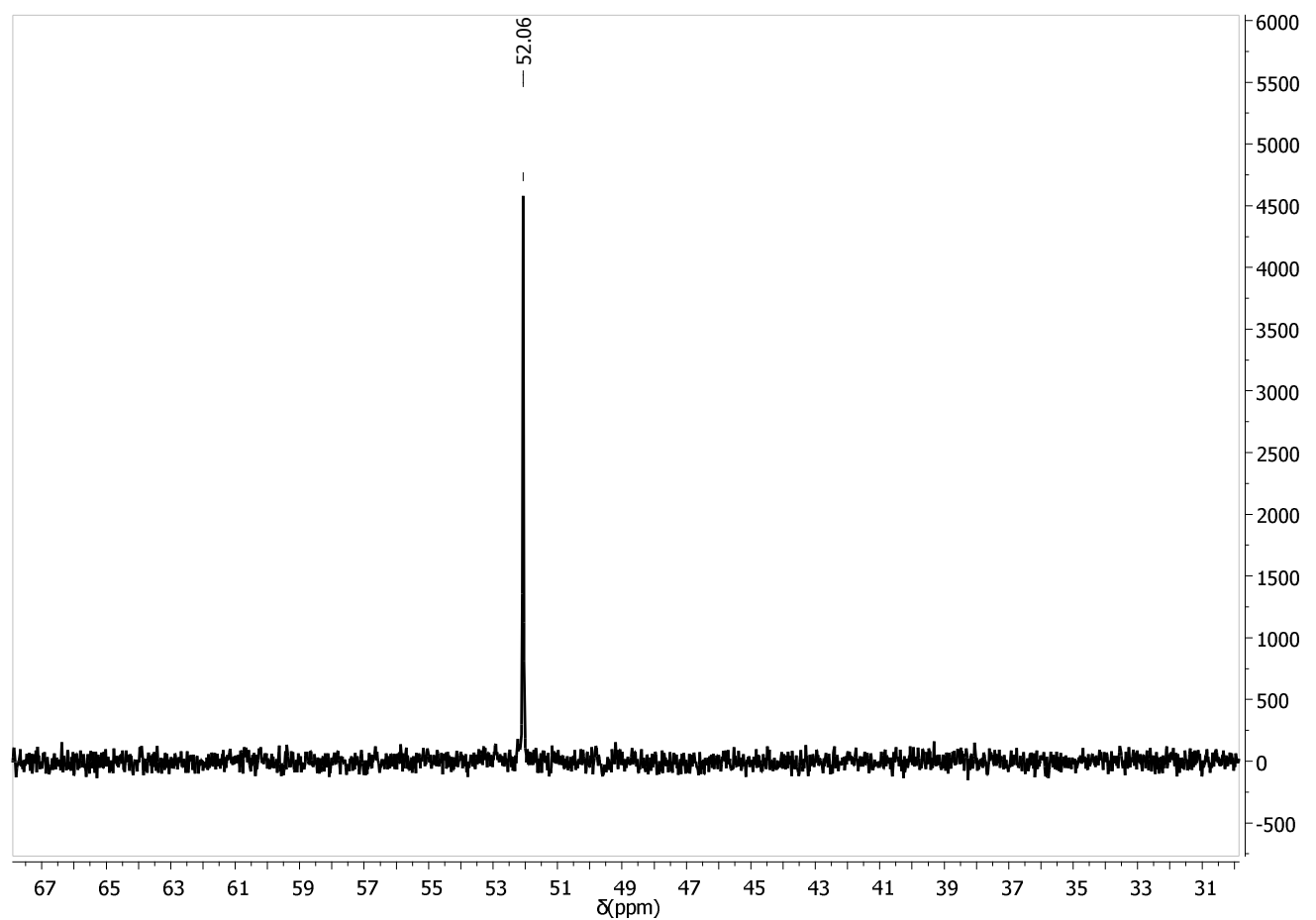

Figure S6: ${ }^{31} \mathrm{P}-\mathrm{NMR}$ spectrum of the product formed in for the reaction of $\mathbf{1}$ with piperidine in $[\mathrm{Bmim}] \mathrm{NTf}_{2}$ at $25^{\circ} \mathrm{C}$.

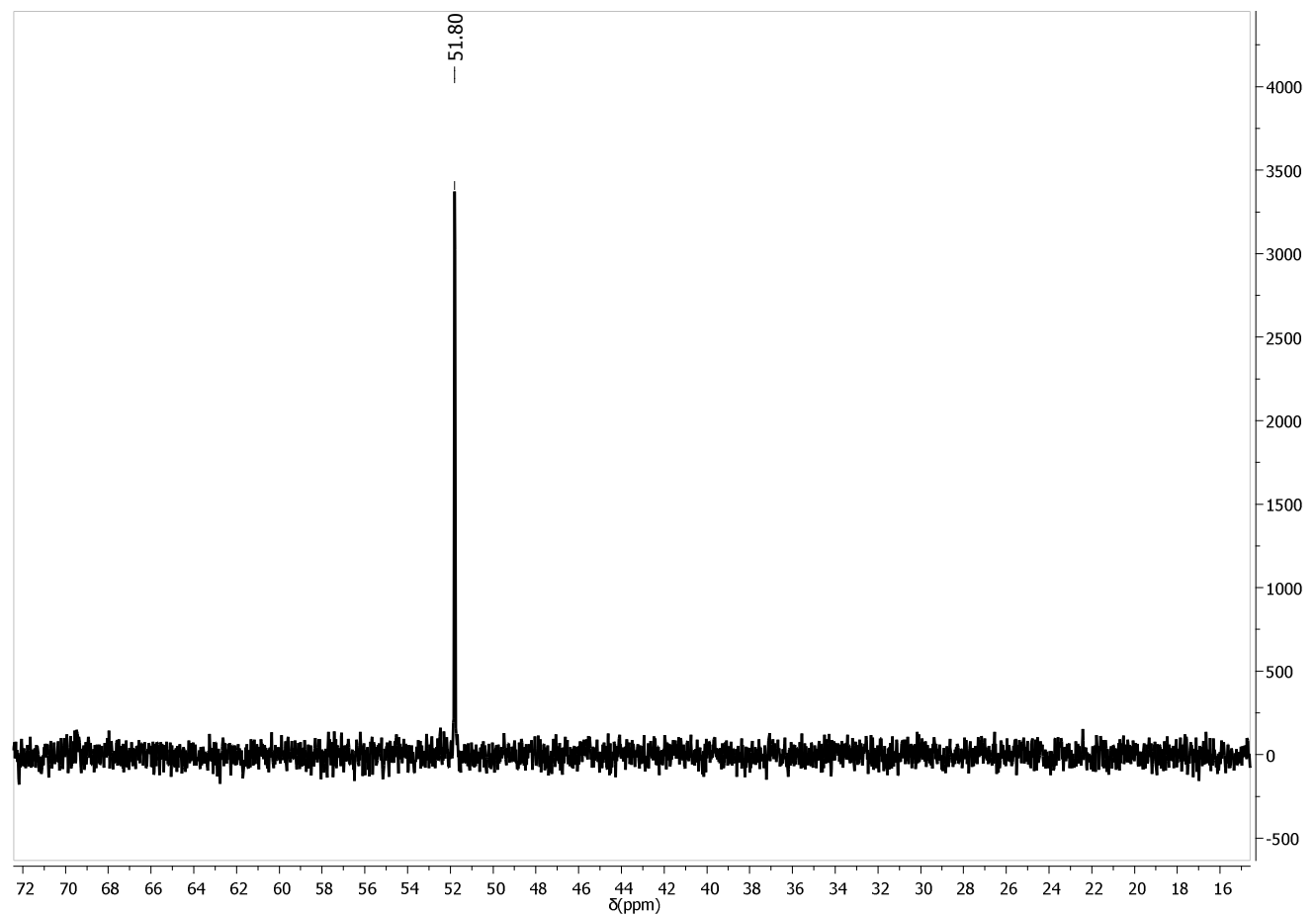

Figure S7: ${ }^{31} \mathrm{P}-\mathrm{NMR}$ spectrum of the product formed in the reaction of $\mathbf{1}$ with piperidine in [Bmim]DCA at $25^{\circ} \mathrm{C}$. 


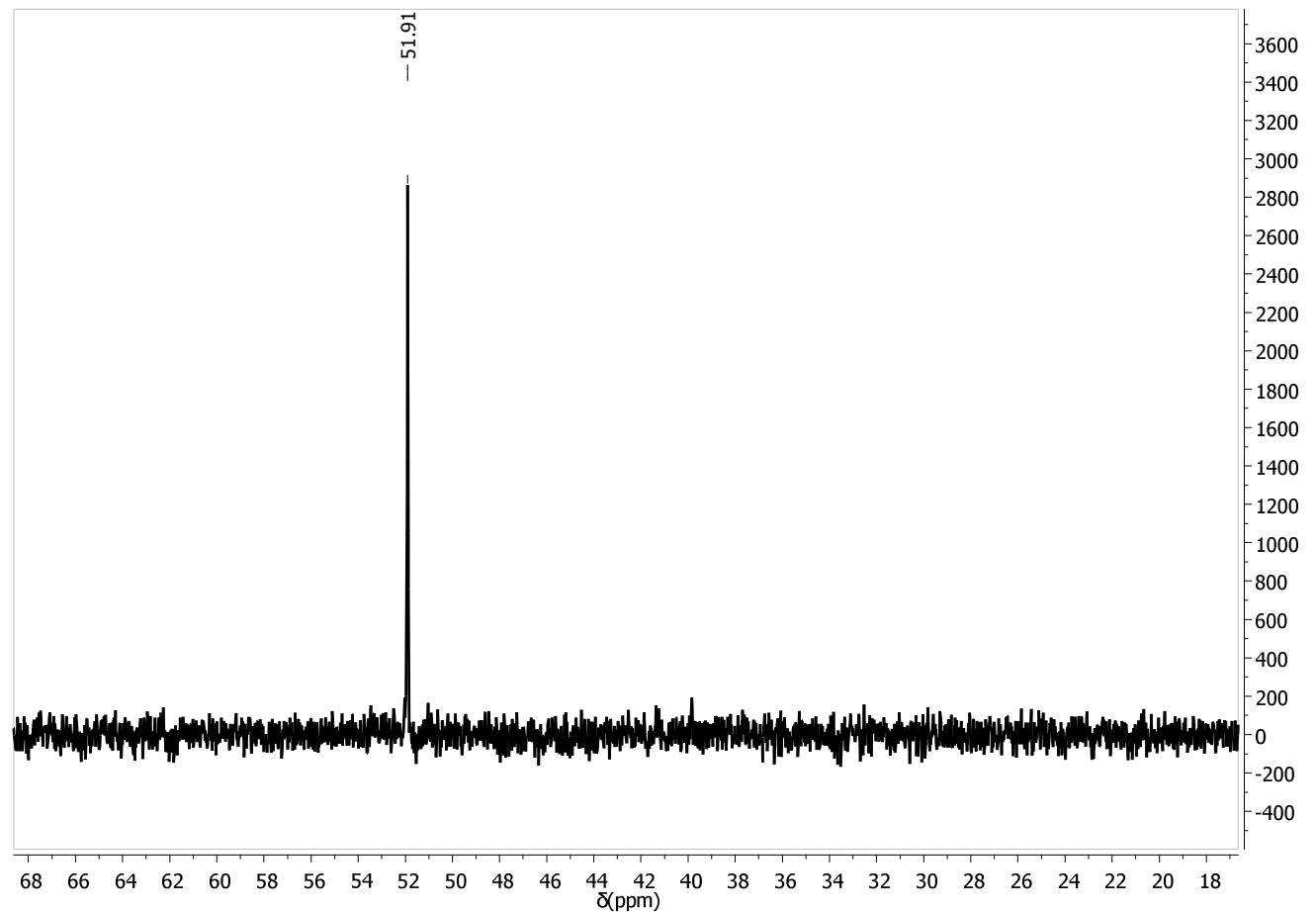

Figure S8: ${ }^{31} \mathrm{P}-\mathrm{NMR}$ spectrum of the product formed in the reaction of $\mathbf{1}$ with piperidine in [Bmim]OTf at $25^{\circ} \mathrm{C}$.

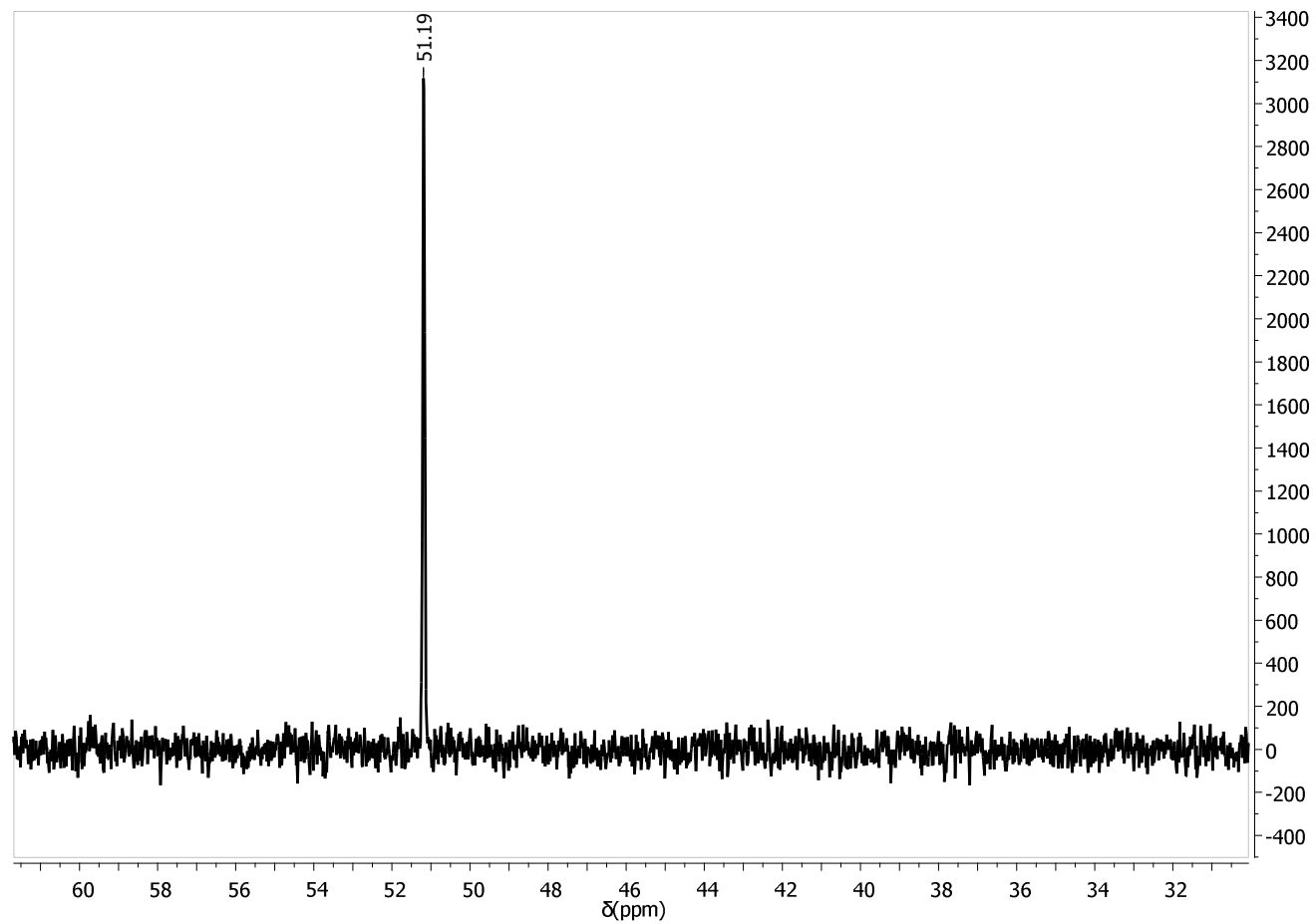

Figure S9: ${ }^{31} \mathrm{P}-\mathrm{NMR}$ spectrum of the product formed in the reaction of $\mathbf{1}$ with piperidine in [Bmpyrr]DCA at $25^{\circ} \mathrm{C}$. 


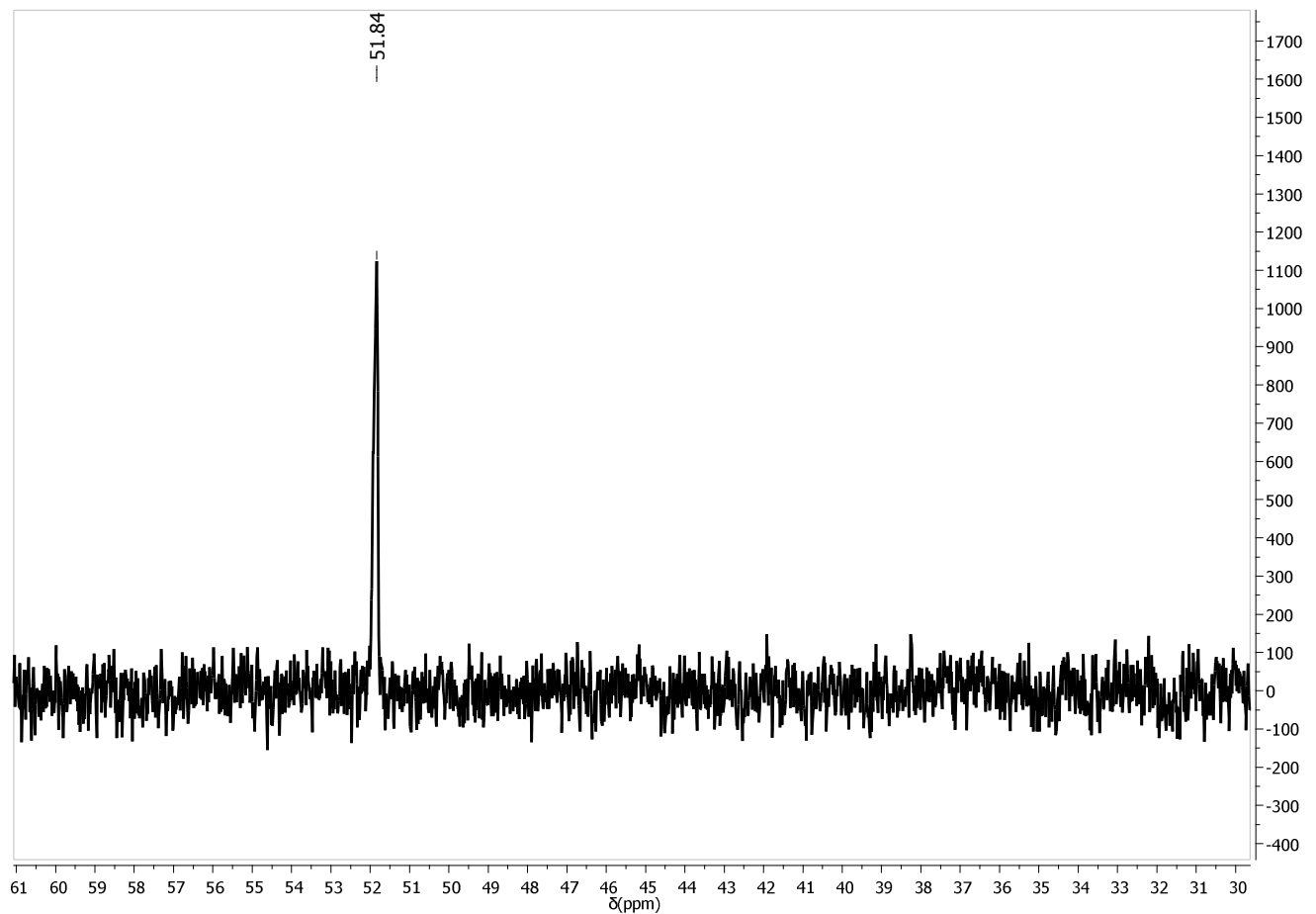

Figure S10: ${ }^{31} \mathrm{P}-\mathrm{NMR}$ spectrum of the product formed in the reaction of $\mathbf{1}$ with piperidine in [Bmpyrr] $\left[\mathrm{Tf}_{2} \mathrm{~N}\right]$ at $25^{\circ} \mathrm{C}$.

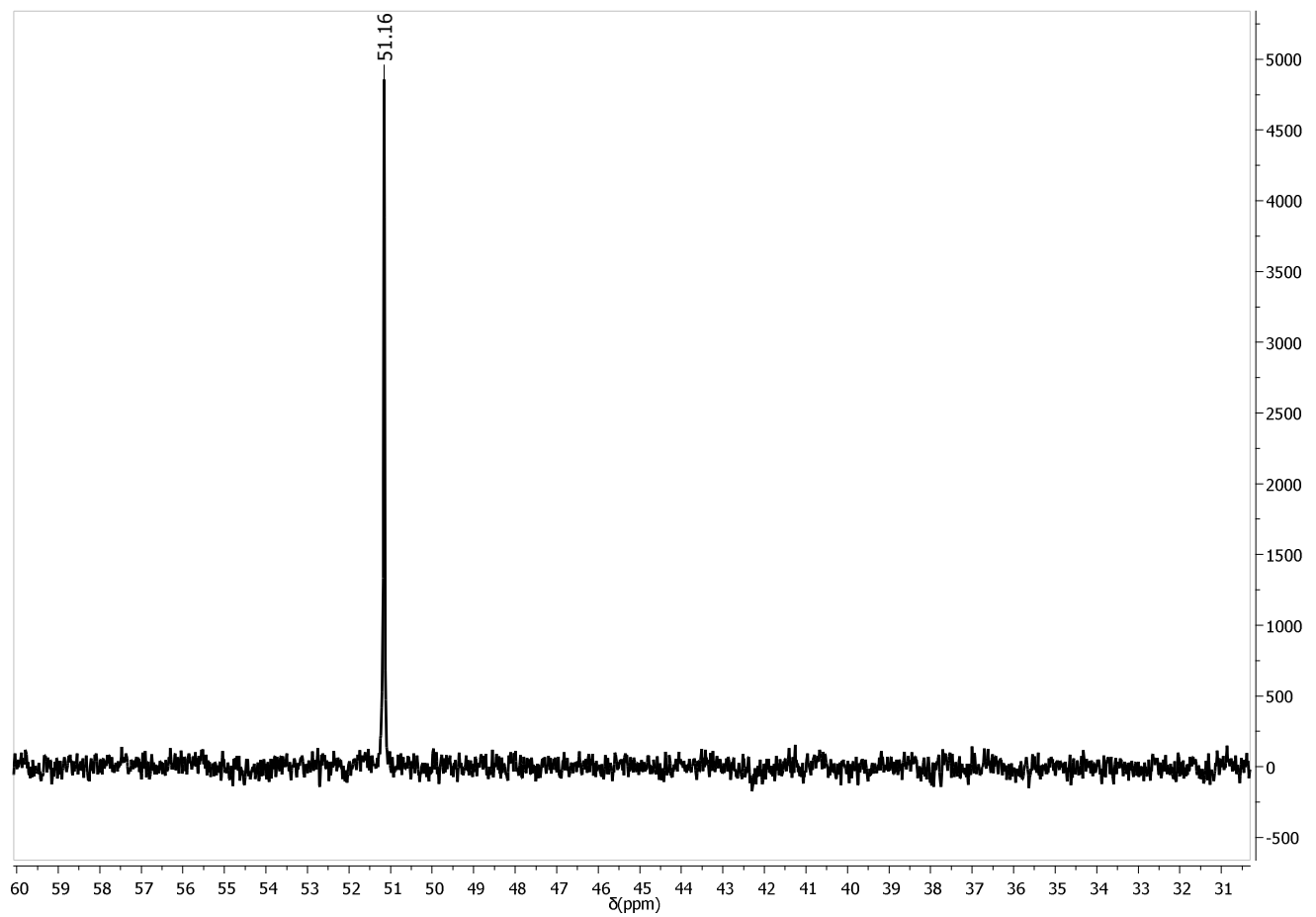

Figure S11: ${ }^{31} \mathrm{P}-\mathrm{NMR}$ spectrum of the product formed in the reaction of $\mathbf{1}$ with piperidine in $[\mathrm{Em} 2 \mathrm{pAm}]\left[\mathrm{Tf}_{2} \mathrm{~N}\right]$ at $25^{\circ} \mathrm{C}$. 


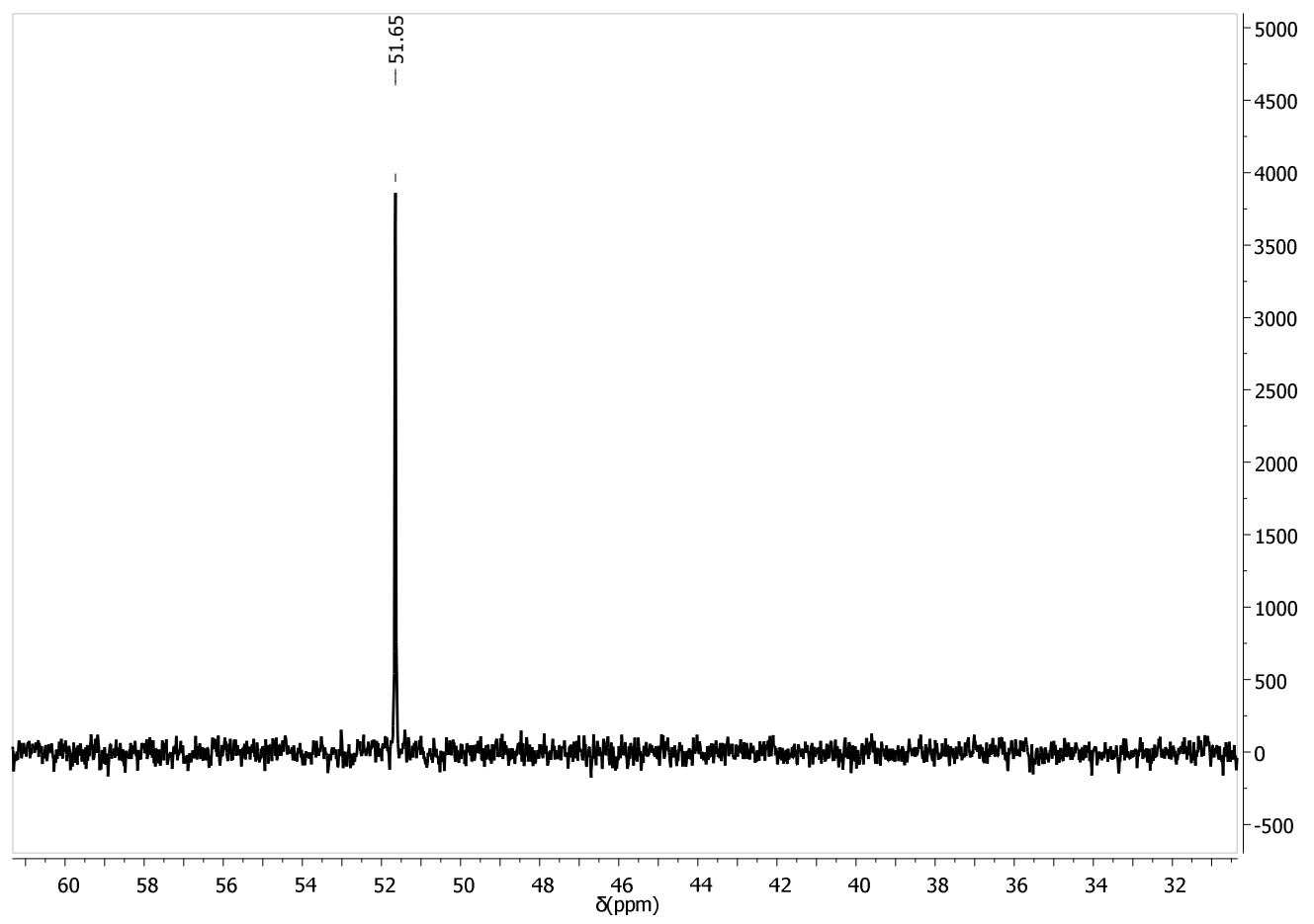

Figure S12: ${ }^{31} \mathrm{P}-\mathrm{NMR}$ spectrum of the product formed in the reaction of $\mathbf{1}$ with piperidine in $\left[\mathrm{B}_{2} \mathrm{mim}\right][\mathrm{OTf}]$ at $25^{\circ} \mathrm{C}$.

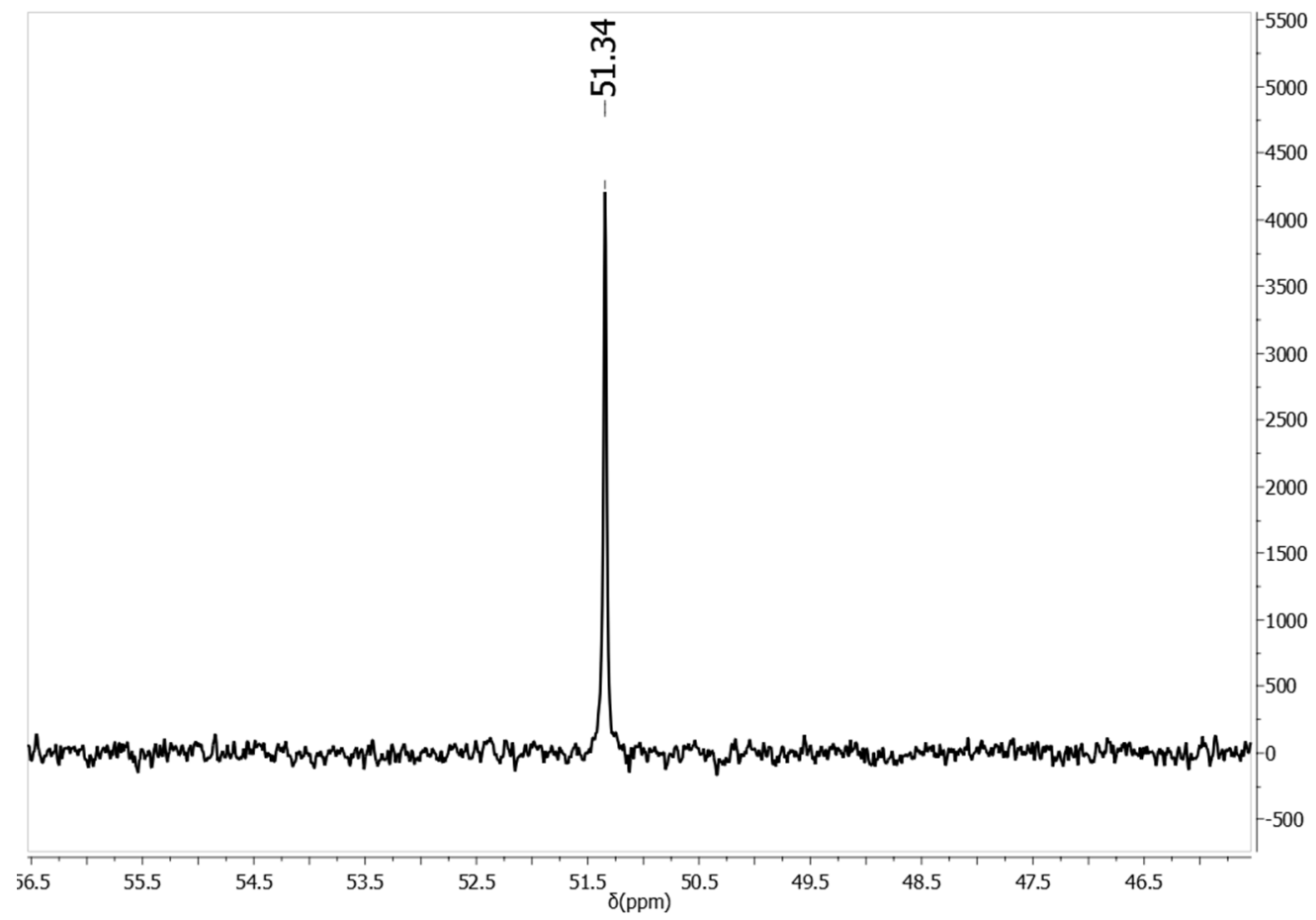

Figure S13: ${ }^{31} \mathrm{P}-\mathrm{NMR}$ spectrum of the product formed in the reaction of 1 with piperidine in [Bmpyrr][OTf] at $25^{\circ} \mathrm{C}$. 


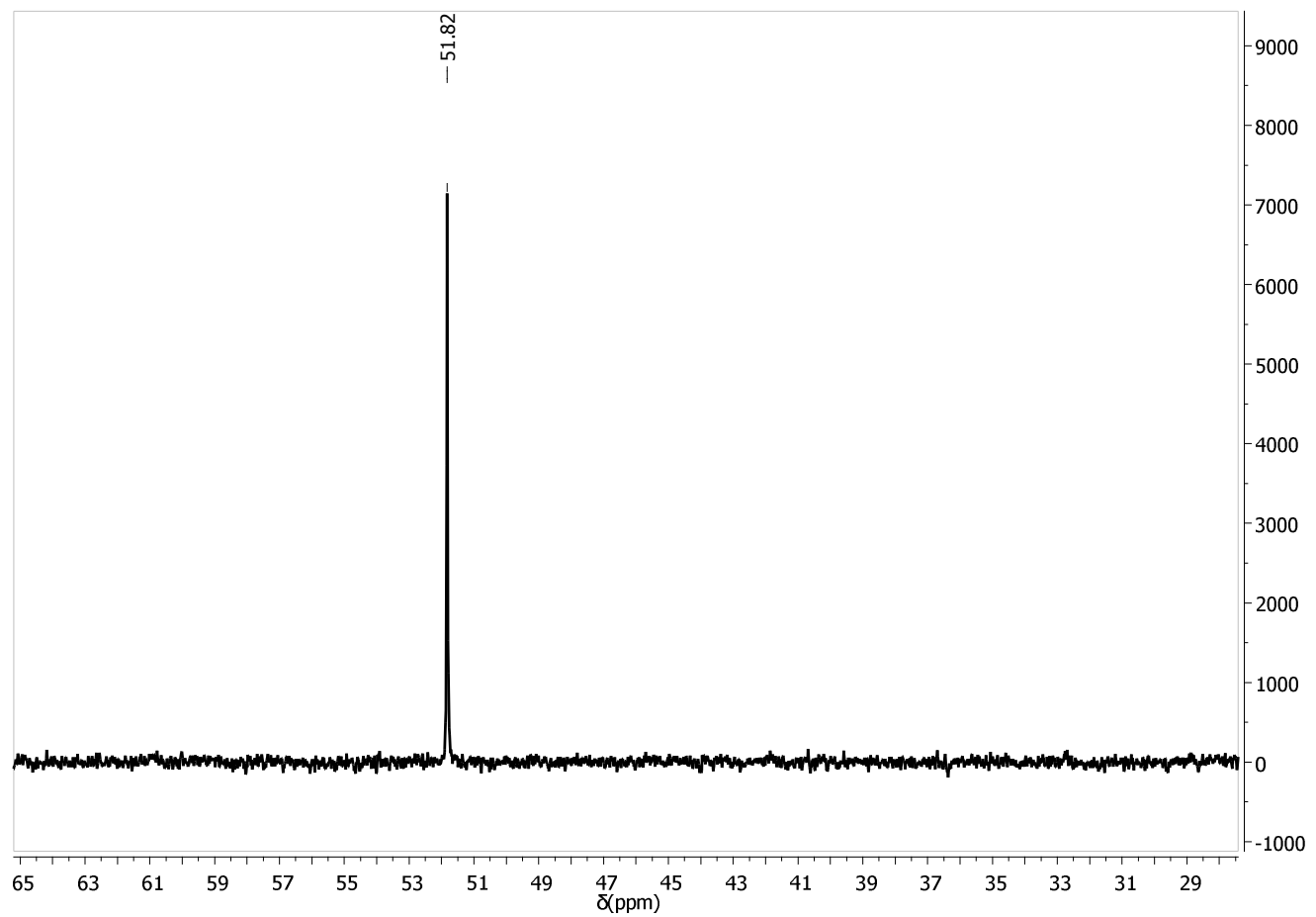

Figure S14: ${ }^{31} \mathrm{P}-\mathrm{NMR}$ spectrum of the product formed in the reaction of $\mathbf{1}$ with piperidine in $\left[\mathrm{B}_{2} \mathrm{mim}\right]\left[\mathrm{Tf}_{2} \mathrm{~N}\right]$ at $25^{\circ} \mathrm{C}$.

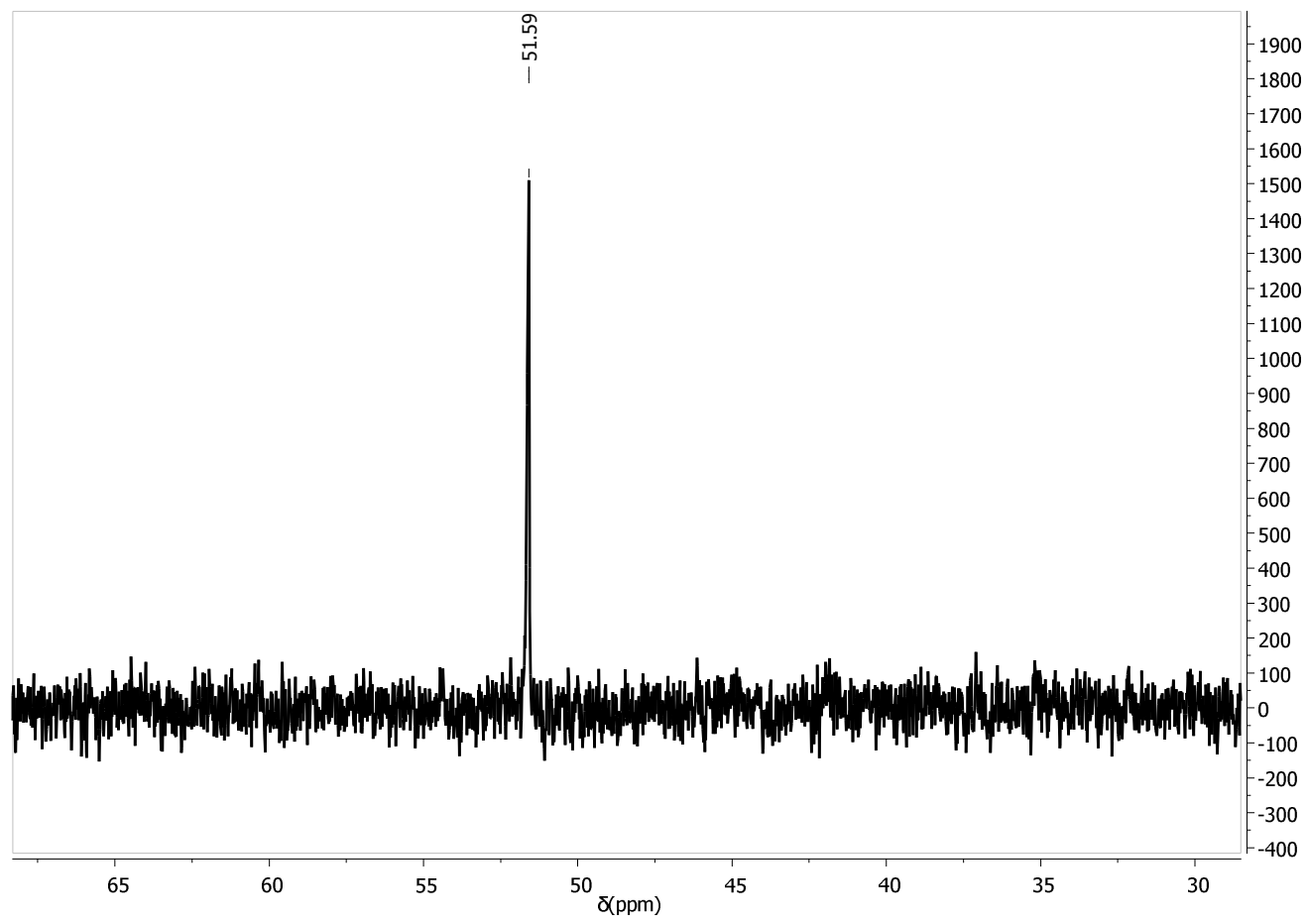

Figure S15: ${ }^{31} \mathrm{P}-\mathrm{NMR}$ spectrum of the product formed in the reaction of 1 with piperidine in $\left[\mathrm{B}_{2} \mathrm{mim}\right]\left[\mathrm{BF}_{4}\right]$ at $25^{\circ} \mathrm{C}$. 


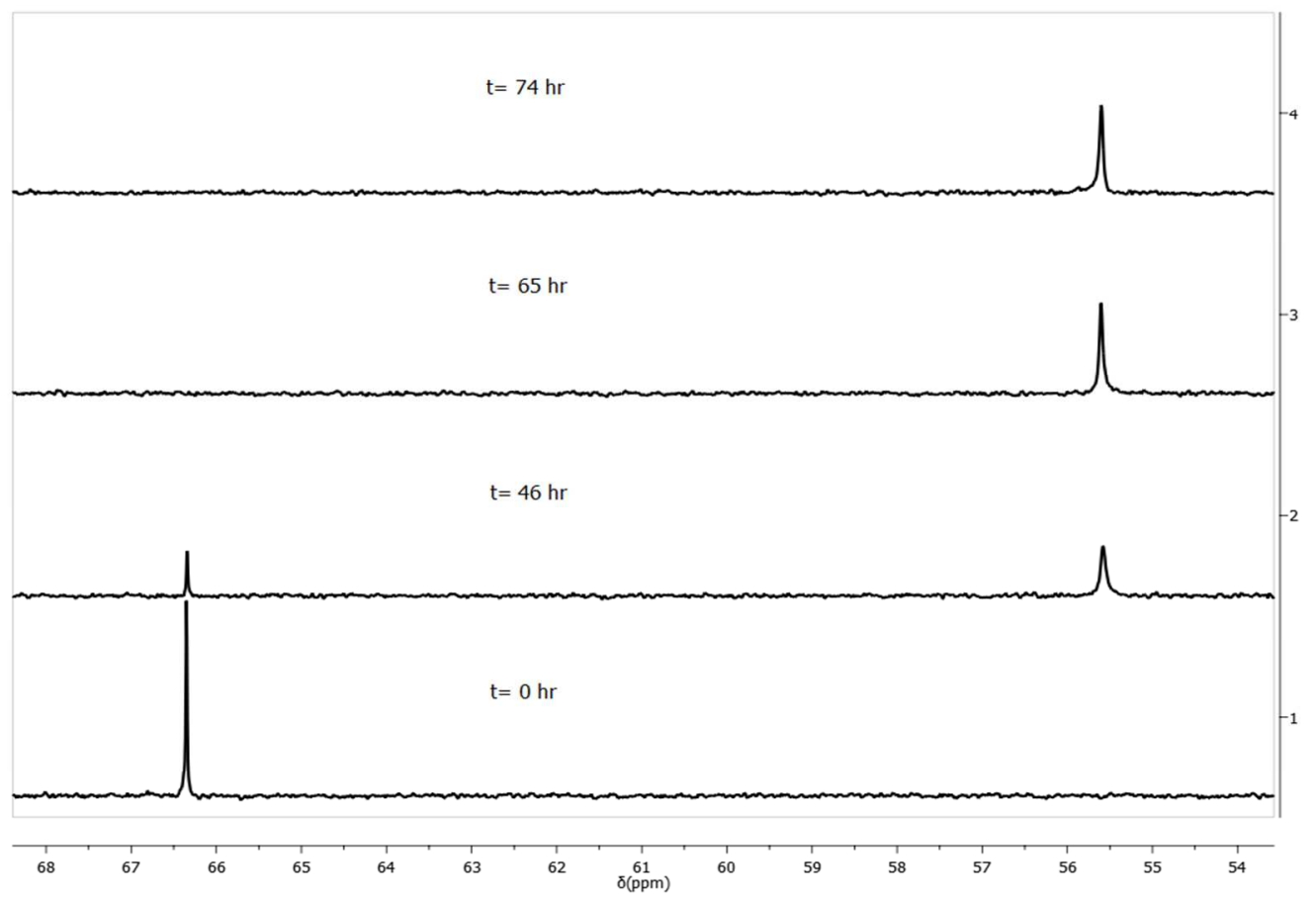

Figure S16: Stacked ${ }^{31} \mathrm{P}-\mathrm{NMR}$ plot for the reaction of 1 with piperidine in 2-MeTHF at $25^{\circ} \mathrm{C}$.

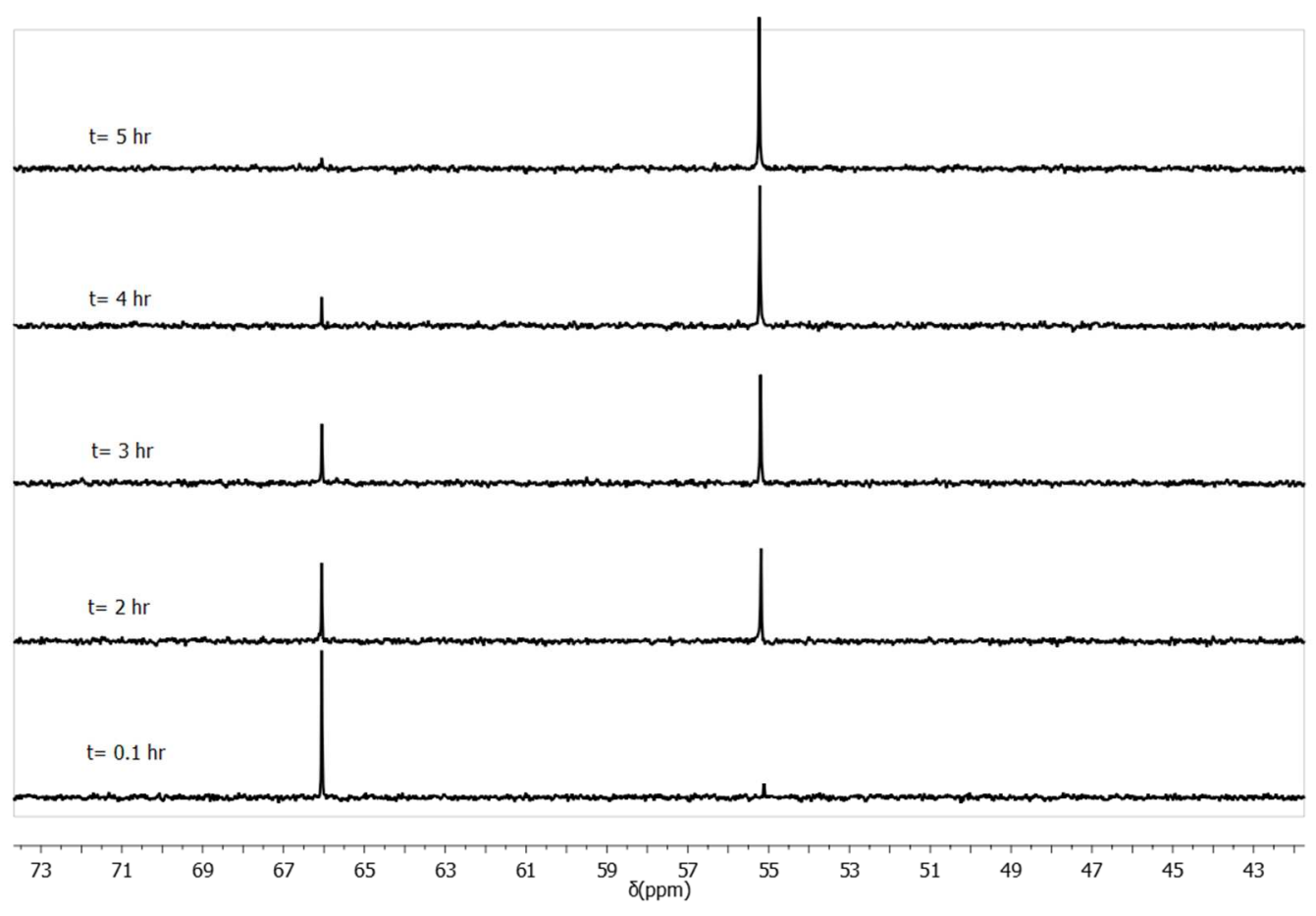

Figure S17: Stacked ${ }^{31}$ P-NMR plot for the reaction of Fenitrothion with piperidine in Cymene at $25^{\circ} \mathrm{C}$. 


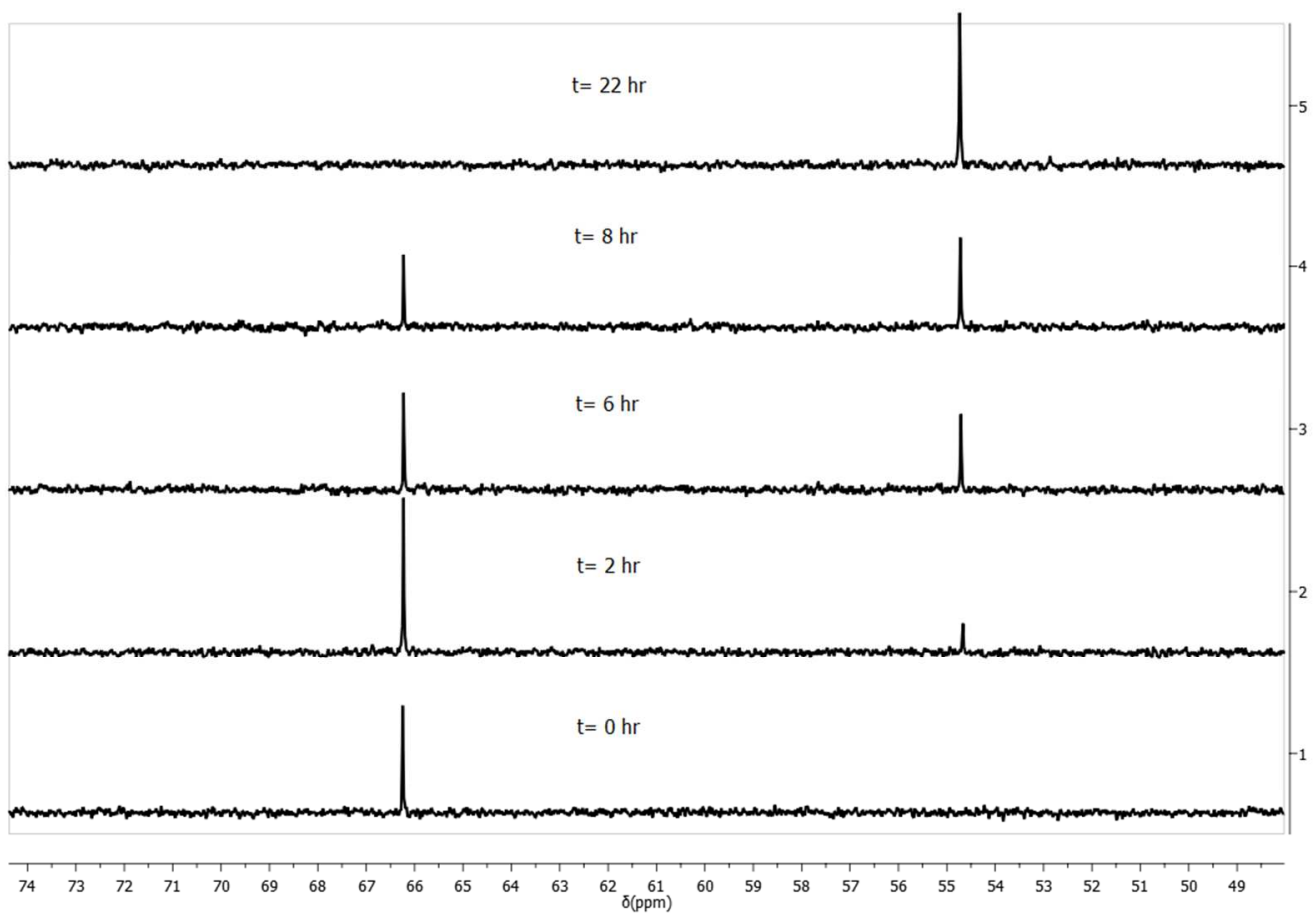

Figure S18: Stacked ${ }^{31} \mathrm{P}-\mathrm{NMR}$ plot for the reaction of 1 with piperidine in Ethyl Lactate at $25^{\circ} \mathrm{C}$.

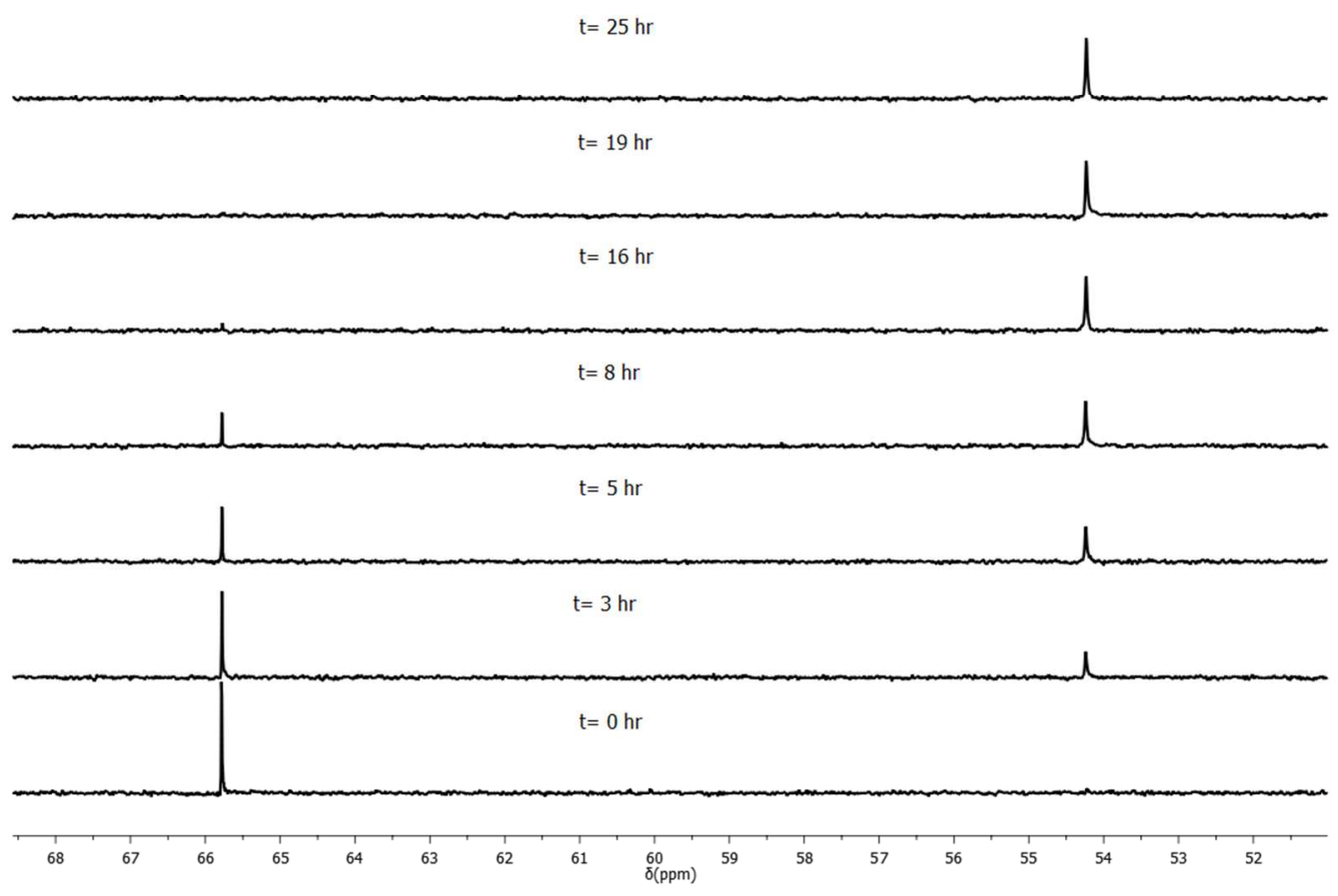

Figure S19: Stacked ${ }^{31}$ P-NMR plot for the reaction of 1 with piperidine in Lymonene at $25^{\circ} \mathrm{C}$. 


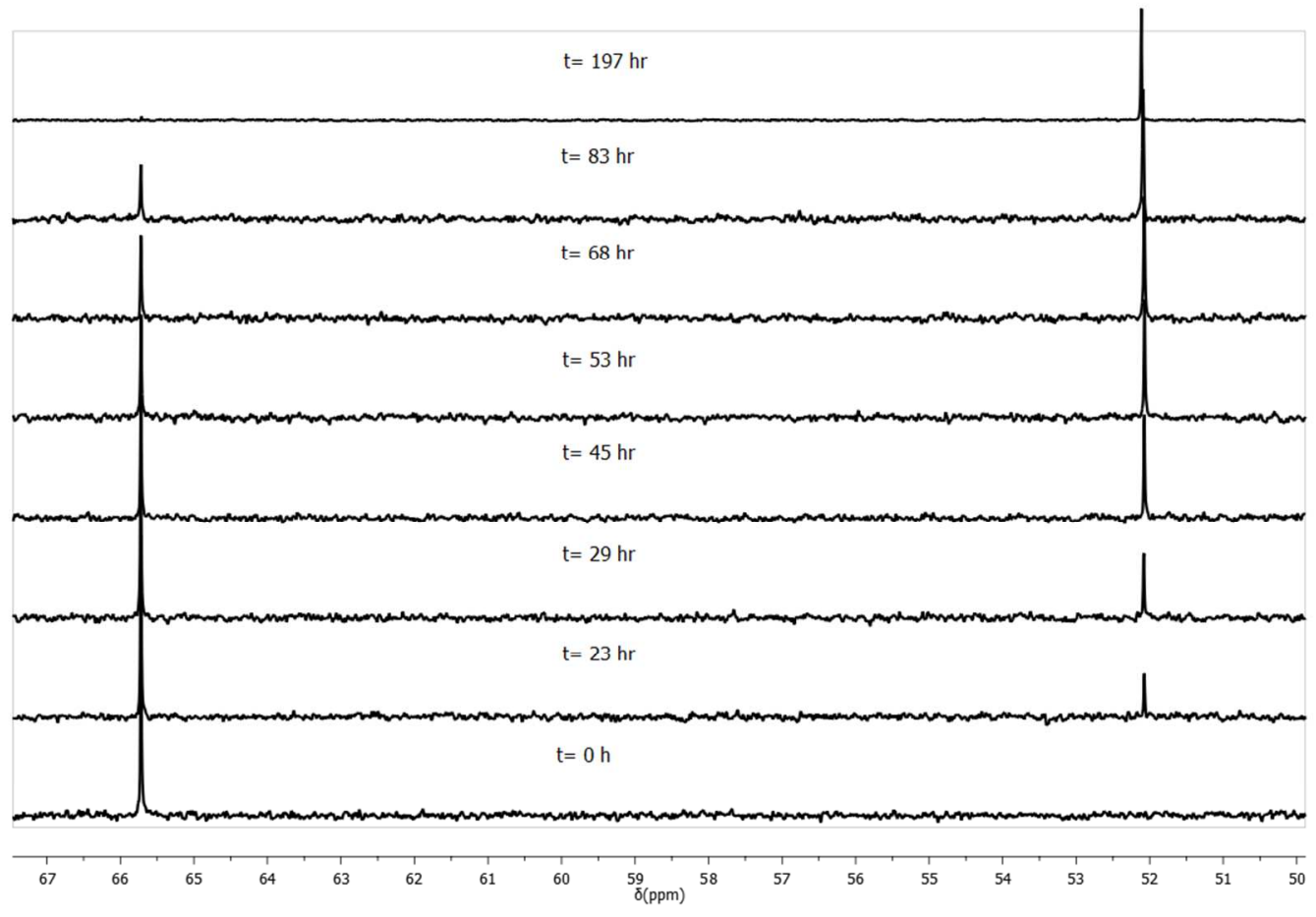

Figure S20: Stacked ${ }^{31} \mathrm{P}-\mathrm{NMR}$ plot for the reaction of 1 with piperidine in $\mathrm{PC}$ at $25^{\circ} \mathrm{C}$.

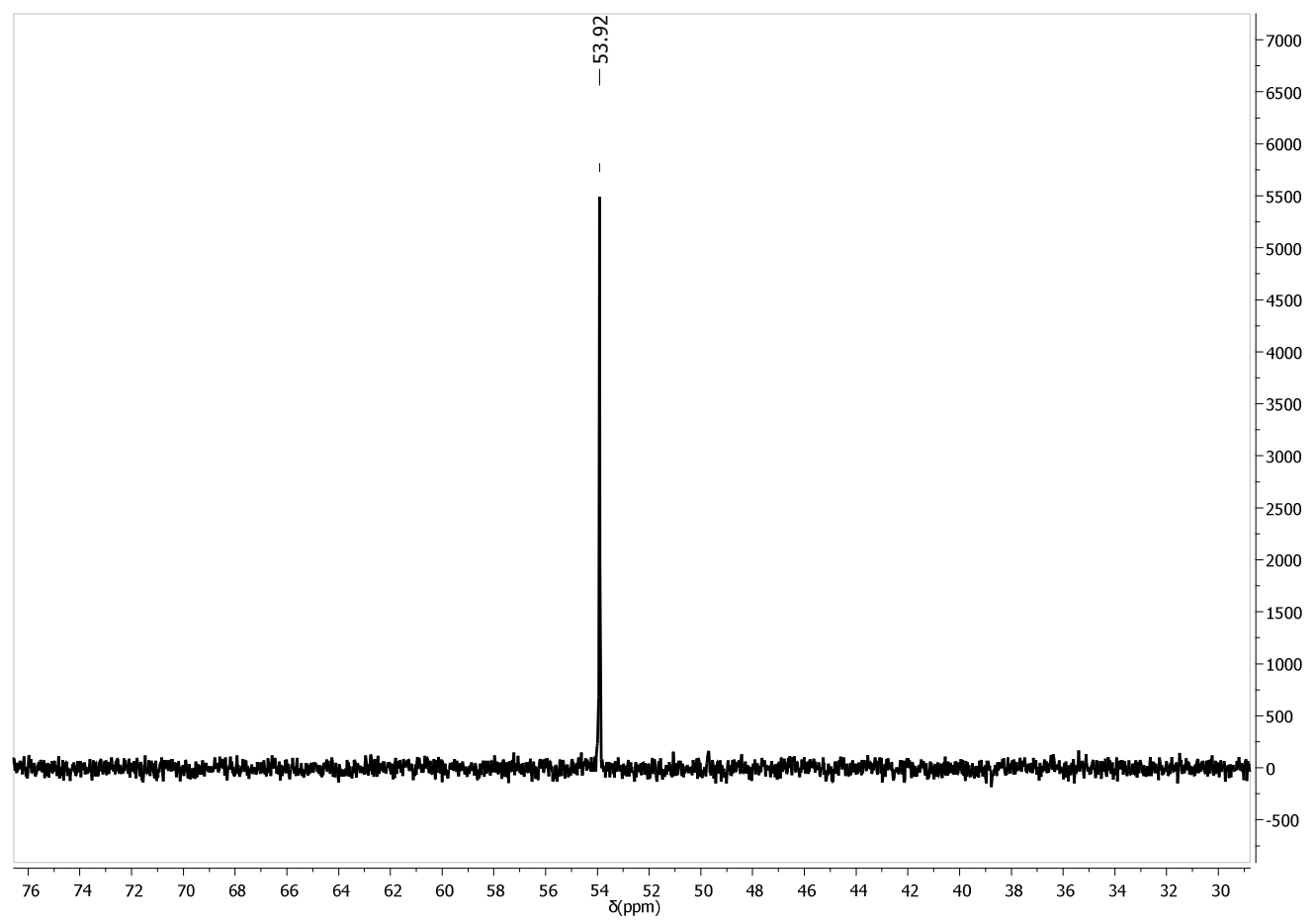

Figure S21: ${ }^{31} \mathrm{P}-\mathrm{NMR}$ plot for the reaction of 1 with piperidine in $\mathrm{MeCN}$ at $25^{\circ} \mathrm{C}$. 


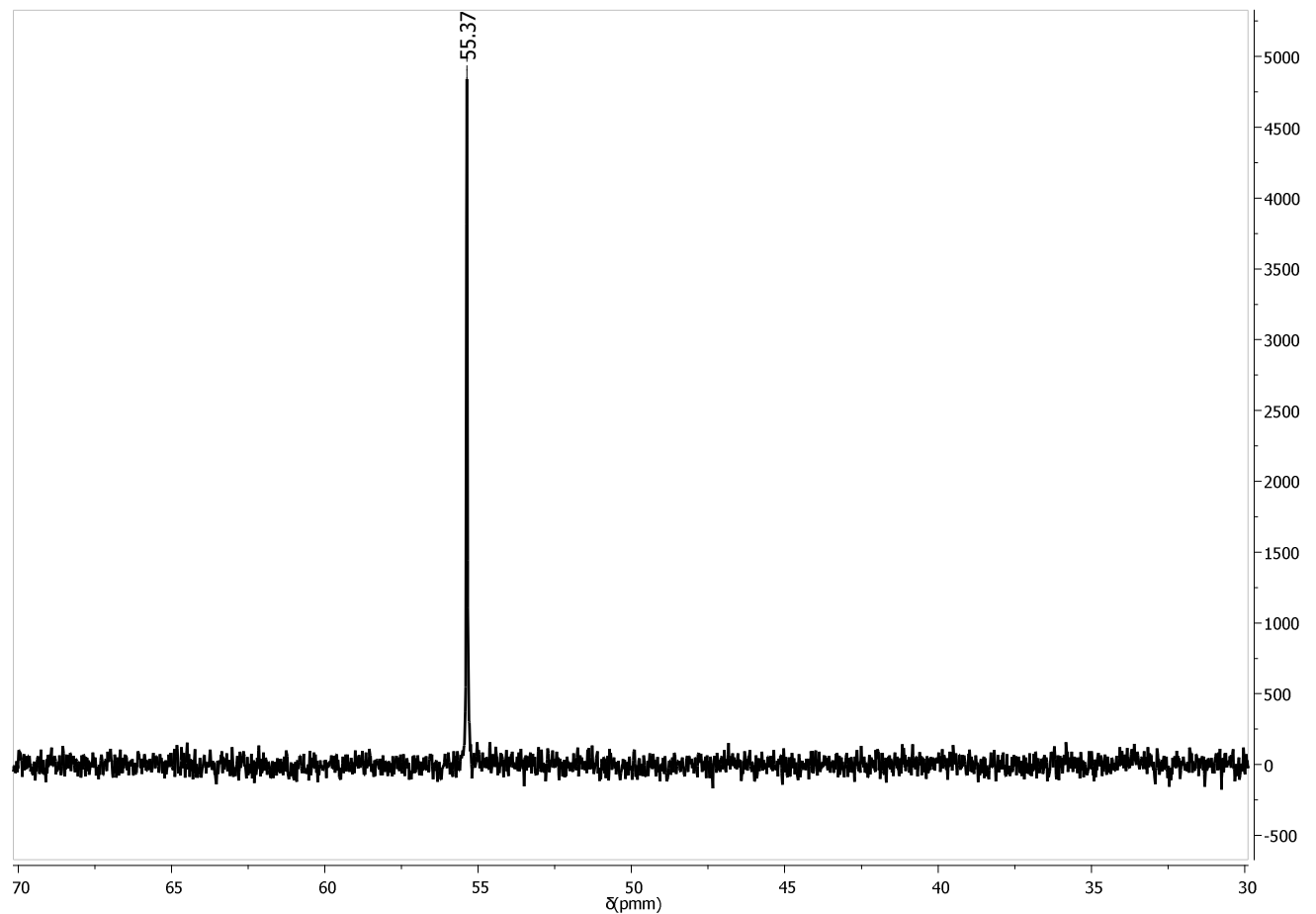

Figure S22: ${ }^{31} \mathrm{P}-\mathrm{NMR}$ plot for the reaction of $\mathbf{1}$ with piperidine in dioxane at $25^{\circ} \mathrm{C}$.

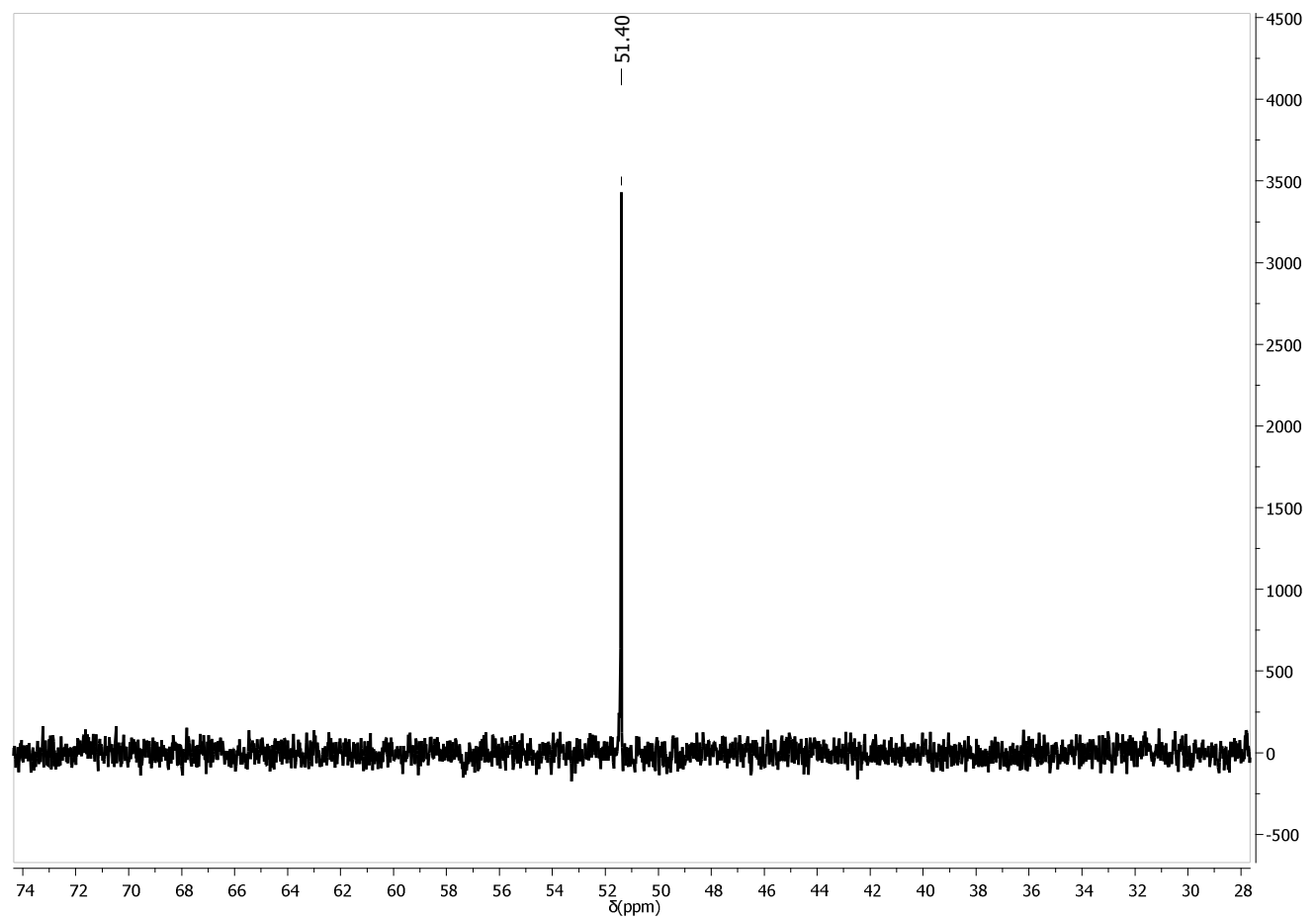

Figure S23: ${ }^{31} \mathrm{P}-\mathrm{NMR}$ plot for the reaction of 1 with piperidine in DMSO at $25^{\circ} \mathrm{C}$. 
Table S3. Viscosity, Kamlet-Taft descriptors and first-order rate constants $\left(k_{\text {obsd }}\right)$ for degradation of $\mathbf{1}$ and $\mathbf{2}$ with piperidine.

\begin{tabular}{|c|c|c|c|c|c|c|c|}
\hline \multirow[t]{2}{*}{ Solvent } & \multirow[t]{2}{*}{$\eta, 25^{\circ} \mathrm{C}(\mathrm{mPas})$} & \multirow[t]{2}{*}{$\alpha$} & \multirow[t]{2}{*}{$\beta$} & \multirow[t]{2}{*}{$\pi^{*}$} & \multirow[t]{2}{*}{$\delta_{\mathrm{H}}$} & \multirow{2}{*}{$\frac{1}{t_{1 / 2}, h}$} & \multirow{2}{*}{$\begin{array}{c}\mathbf{2} \\
t_{1 / 2, h},\end{array}$} \\
\hline & & & & & & & \\
\hline Water & $0.89^{19}$ & 1.12 & 0.5 & $1.33^{34}$ & $48.0^{35}$ & 6.42 & $1.02^{\mathrm{a}}$ \\
\hline $\mathrm{MeCN}$ & $0.34^{36}$ & 0.35 & 0.37 & $0.80^{37}$ & $24.2^{20}$ & 0.27 & $8.96^{\mathrm{a}}$ \\
\hline Dioxane & $1.18^{38}$ & 0.00 & 0.37 & $0.55^{35}$ & $20.5^{20}$ & 0.69 & $30.1^{\mathrm{a}}$ \\
\hline DMSO & $1.96^{36}$ & 0.00 & 0.74 & $1.00^{39}$ & $26.6^{20}$ & 0.080 & - \\
\hline CYM & $0.82^{40}$ & 0.00 & 0.13 & $0.39^{20}$ & $17.4^{20}$ & 1.50 & 0.34 \\
\hline LYM & $0.85^{40}$ & 0.00 & 0.00 & $0.16^{34}$ & $15.1^{20}$ & 5.96 & 0.13 \\
\hline 2-MeTHF & $0.46^{41}$ & 0.00 & 0.58 & $0.53^{34}$ & $16.9^{42}$ & 1.25 & 0.29 \\
\hline EL & $2.53^{43}$ & 0.69 & 0.52 & $0.82^{34}$ & $20.2^{44}$ & 3.32 & 0.05 \\
\hline $\mathrm{PC}$ & $2.50^{19}$ & 0.00 & 0.40 & $0.83^{34}$ & $27.2^{44}$ & 0.17 & - \\
\hline GLU & - & - & - & - & - & - & 0.01 \\
\hline GLY & $934^{19}$ & - & - & - & - & - & - \\
\hline$\left[\mathrm{B}_{2} \operatorname{mim}\right] \mathrm{NTf}_{2}$ & - & 0.38 & 0.30 & $0.99^{39}$ & $21.5^{45}$ & 0.12 & $3.90^{\mathrm{a}}$ \\
\hline$\left[\mathrm{B}_{2} \mathrm{mim}\right] \mathrm{BF}_{4}$ & - & 0.40 & 0.36 & $1.08^{34}$ & $26.8^{45}$ & 0.084 & $4.00^{\mathrm{a}}$ \\
\hline$[\mathrm{Bmim}] \mathrm{BF}_{4}$ & $219^{46}$ & 0.61 & 0.38 & $1.08^{39}$ & $24.3^{45}$ & 0.104 & $1.60^{\mathrm{a}}$ \\
\hline [Bmim]DCA & - & 0.47 & 0.71 & $1.13^{34}$ & $27.9^{45}$ & 0.078 & $1.41^{\mathrm{a}}$ \\
\hline$[\mathrm{Bmim}] \mathrm{PF}_{6}$ & $450^{46}$ & 0.63 & 0.21 & $1.03^{34}$ & $25.8^{45}$ & 0.134 & $2.28^{\mathrm{a}}$ \\
\hline$\left[\mathrm{Em}_{2} \mathrm{PAm}\right] \mathrm{NTf}_{2}$ & $83^{47}$ & - & - & - & - & 0.128 & $5.75^{\mathrm{a}}$ \\
\hline$\left[\mathrm{B}_{2} \operatorname{mim}\right] \mathrm{OTf}$ & - & - & - & - & - & 0.073 & - \\
\hline$[\mathrm{Bmim}] \mathrm{NTf}_{2}$ & $69^{46}$ & 0.94 & 0.23 & 1.09 & $26.7^{48}$ & 0.175 & $2.91^{\mathrm{a}}$ \\
\hline [Bmpyrr] $\mathrm{NTf}_{2}$ & $85^{47}$ & 0.41 & 0.24 & $0.97^{39}$ & $21.2^{45}$ & 0.150 & $7.08^{\mathrm{a}}$ \\
\hline [Bmim]OTf & $90^{46}$ & 0.65 & 0.46 & $1.00^{34}$ & $25.6^{45}$ & 0.110 & - \\
\hline [Bmpyrr]DCA & $509^{47}$ & - & - & - & $25.0^{45}$ & 0.056 & $3.00^{\mathrm{a}}$ \\
\hline [Bmpyrr]OTf & - & 0.4 & 0.46 & $1.02^{48}$ & - & 0.094 & - \\
\hline
\end{tabular}

\footnotetext{
${ }^{a}$ the $k_{\text {obsd }}$ data for calculation of $\mathrm{t}_{1 / 2}$ reported in this table were obtained from reference 17
} 


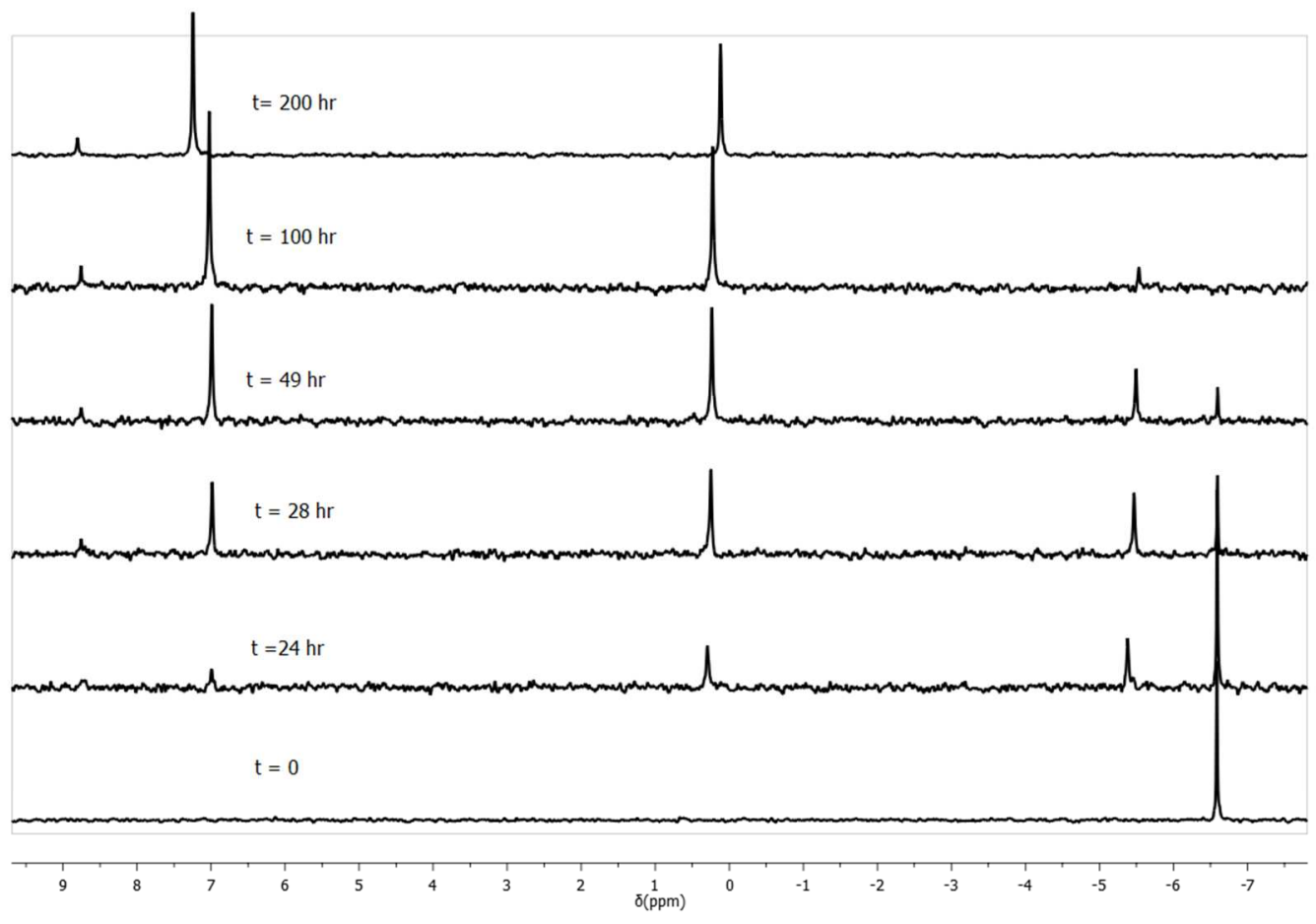

Figure S24: Stacked ${ }^{31} \mathrm{P}-\mathrm{NMR}$ plot for the reaction of $\mathbf{2}$ with piperidine in 2-MeTHF at $25^{\circ} \mathrm{C}$.

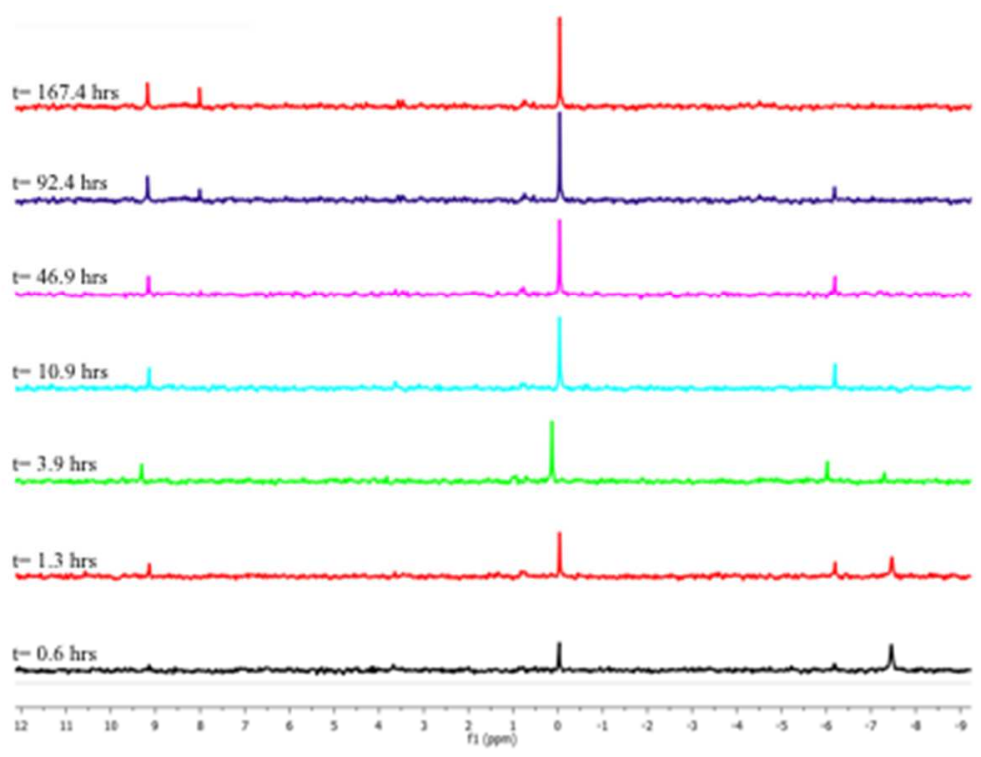

Figure S25. Progressive ${ }^{31} \mathrm{P}$ NMR spectra obtained for degradation of $\mathbf{2}$ with piperidine $(2.8 \mathrm{M})$ at $25^{\circ} \mathrm{C}$ in GLU. 


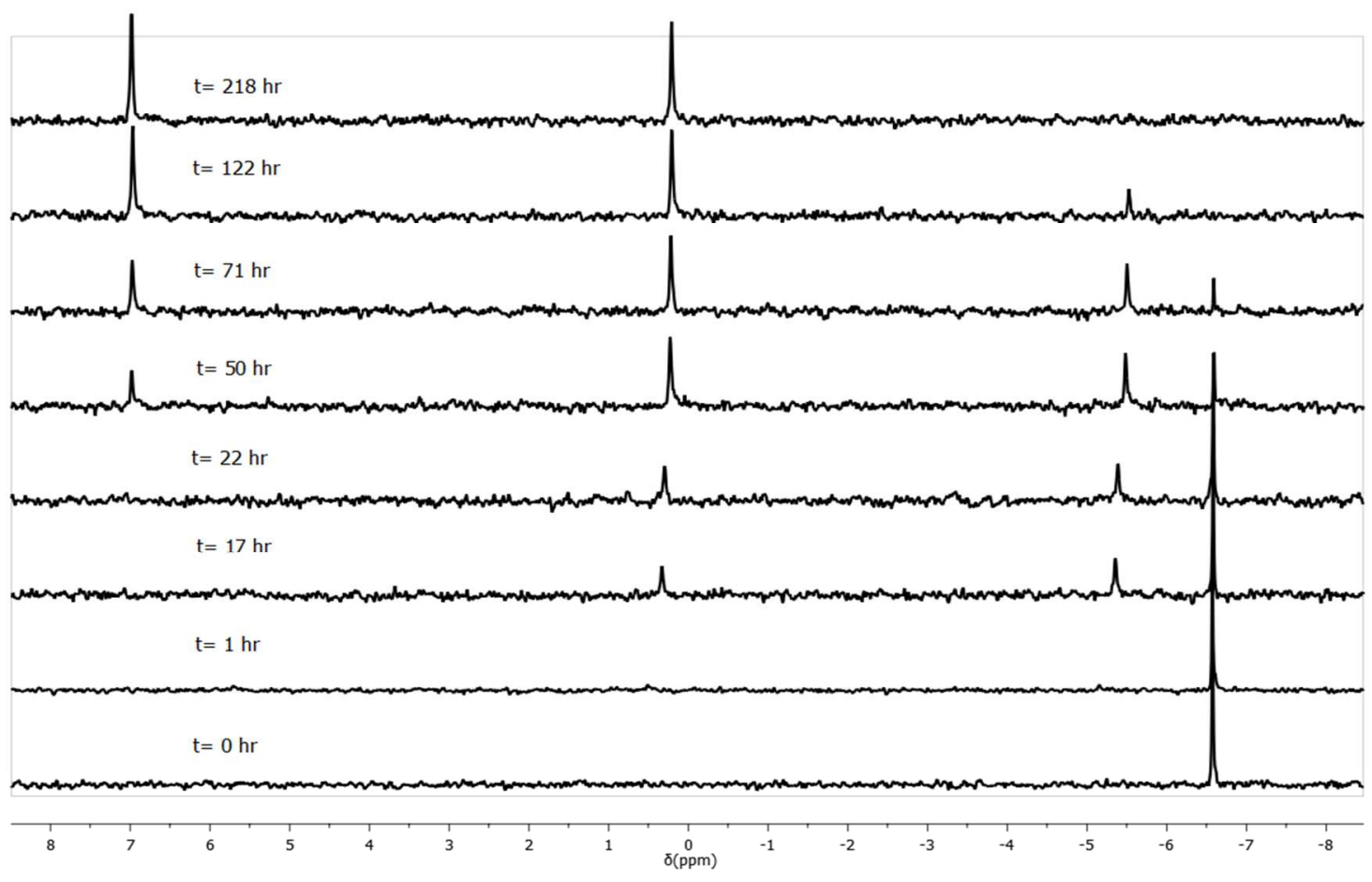

Figure S26: Stacked ${ }^{31} \mathrm{P}-\mathrm{NMR}$ plot for the reaction of $\mathbf{2}$ with piperidine in Cymene at $25^{\circ} \mathrm{C}$.

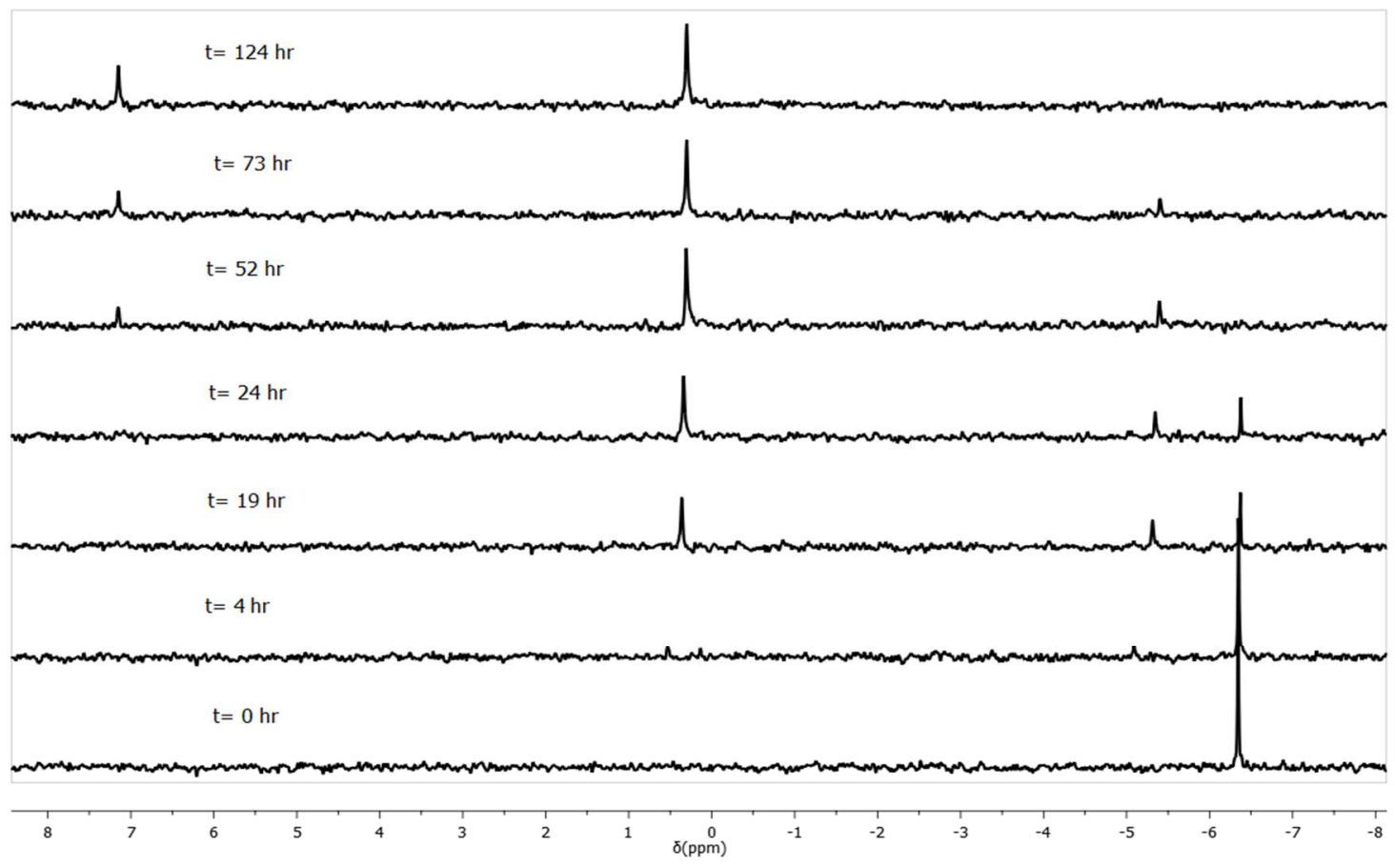

Figure S27: Stacked ${ }^{31}$ P-NMR plot for the reaction of $\mathbf{2}$ with piperidine in Lymonene at $25^{\circ} \mathrm{C}$. 


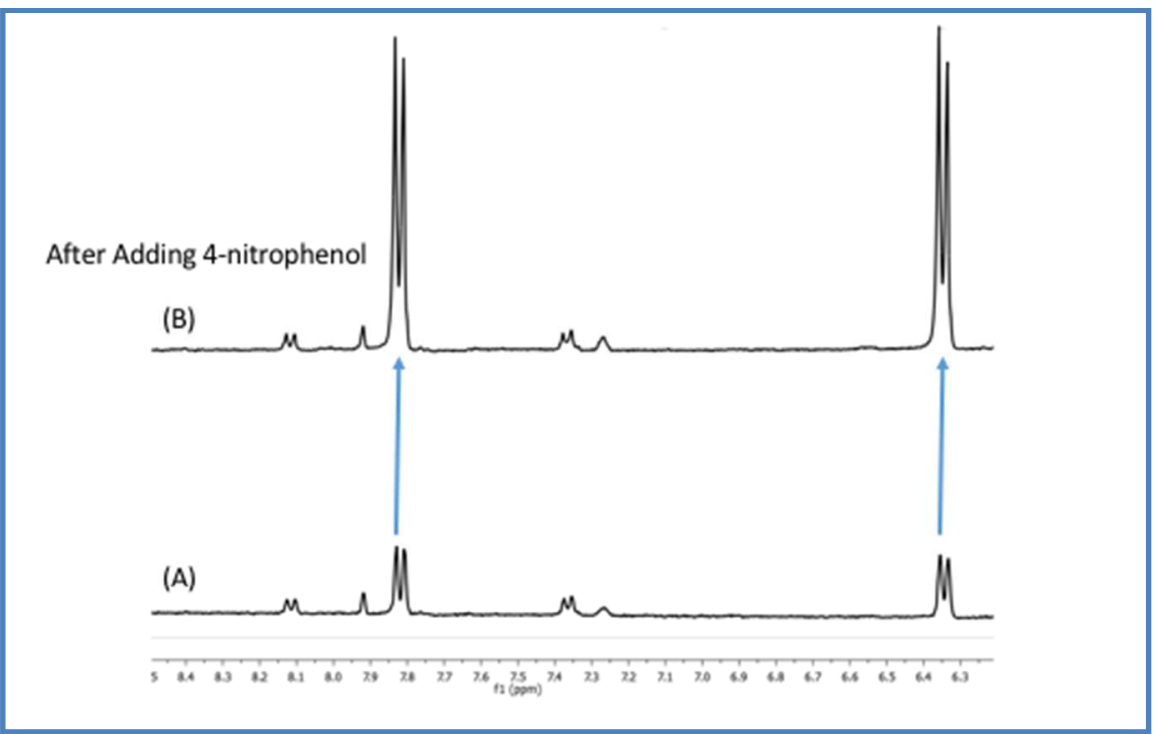

Figure S28: (A) ${ }^{1} \mathrm{H}$ NMR spectra (aromatic region) for degradation of $\mathbf{2}$ with piperidine in EL. (B) After addition of 4-nitrophenol.

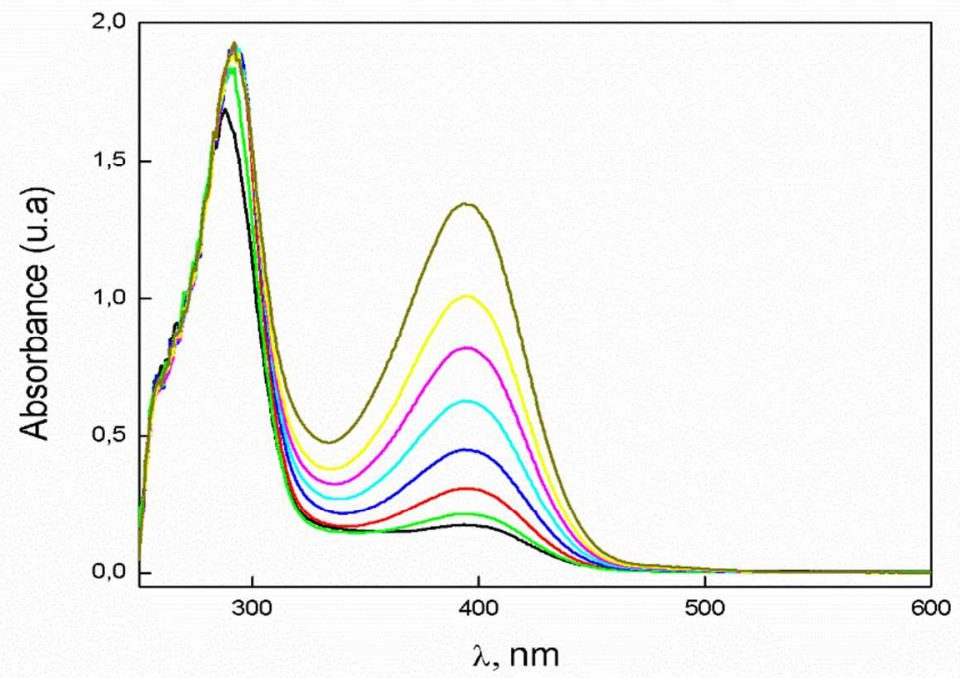

Figure S29: Experimental plot of absorbance $v s$ wavelength for the reaction of piperidine $(2.8 \mathrm{M})$ with 2 in $\mathrm{EL}$ at $25^{\circ} \mathrm{C}$. 
-MS2 (153.00): 71 MCA scans from Sample 1

Max. $3.3 e 6$ cps.

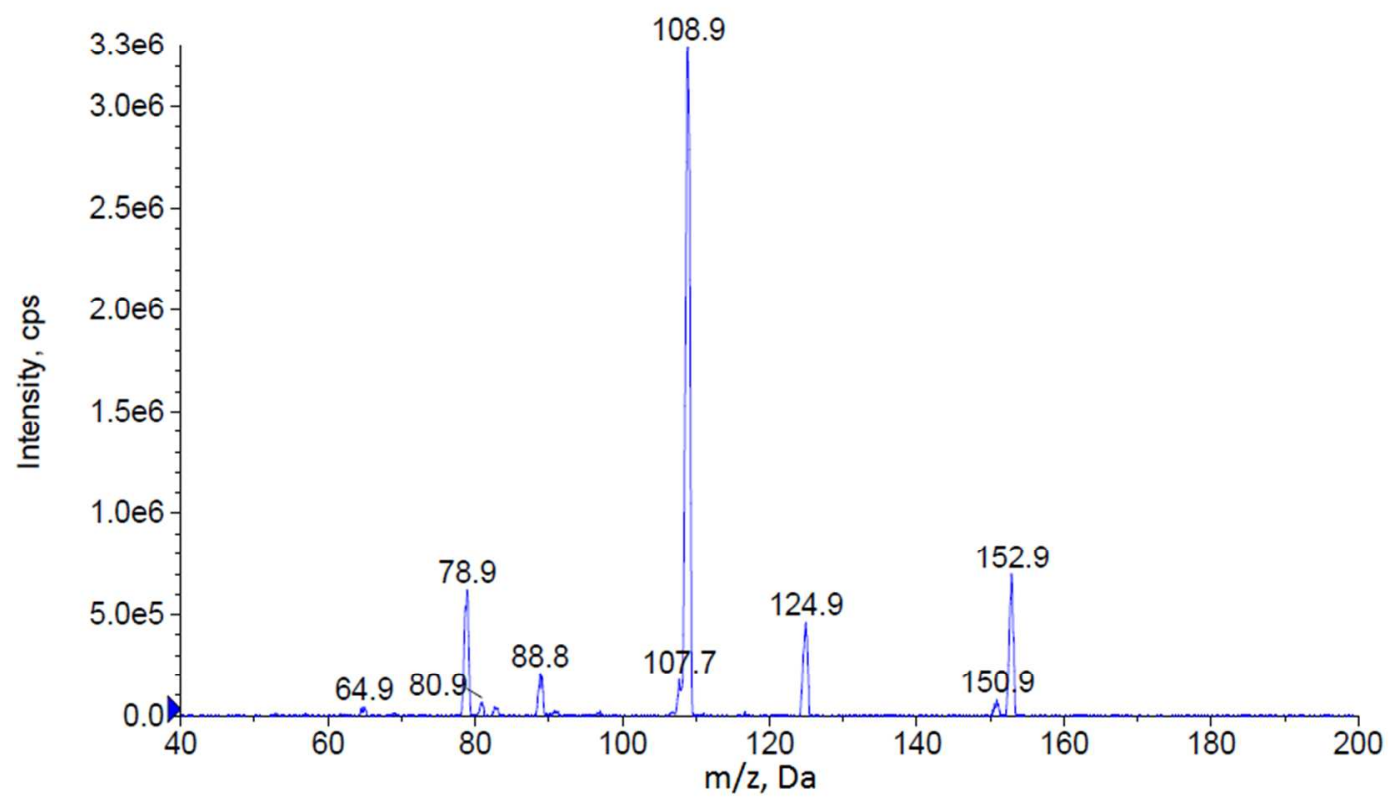

Figure S30: ESI-MS/MS(-) of the compound 4 of $m / z 152.9$, from a reaction of 2 with piperidine in EL

-MS2 (246.00): 55 MCA scans from Sample 1

Max. 3.1 e6 cps.

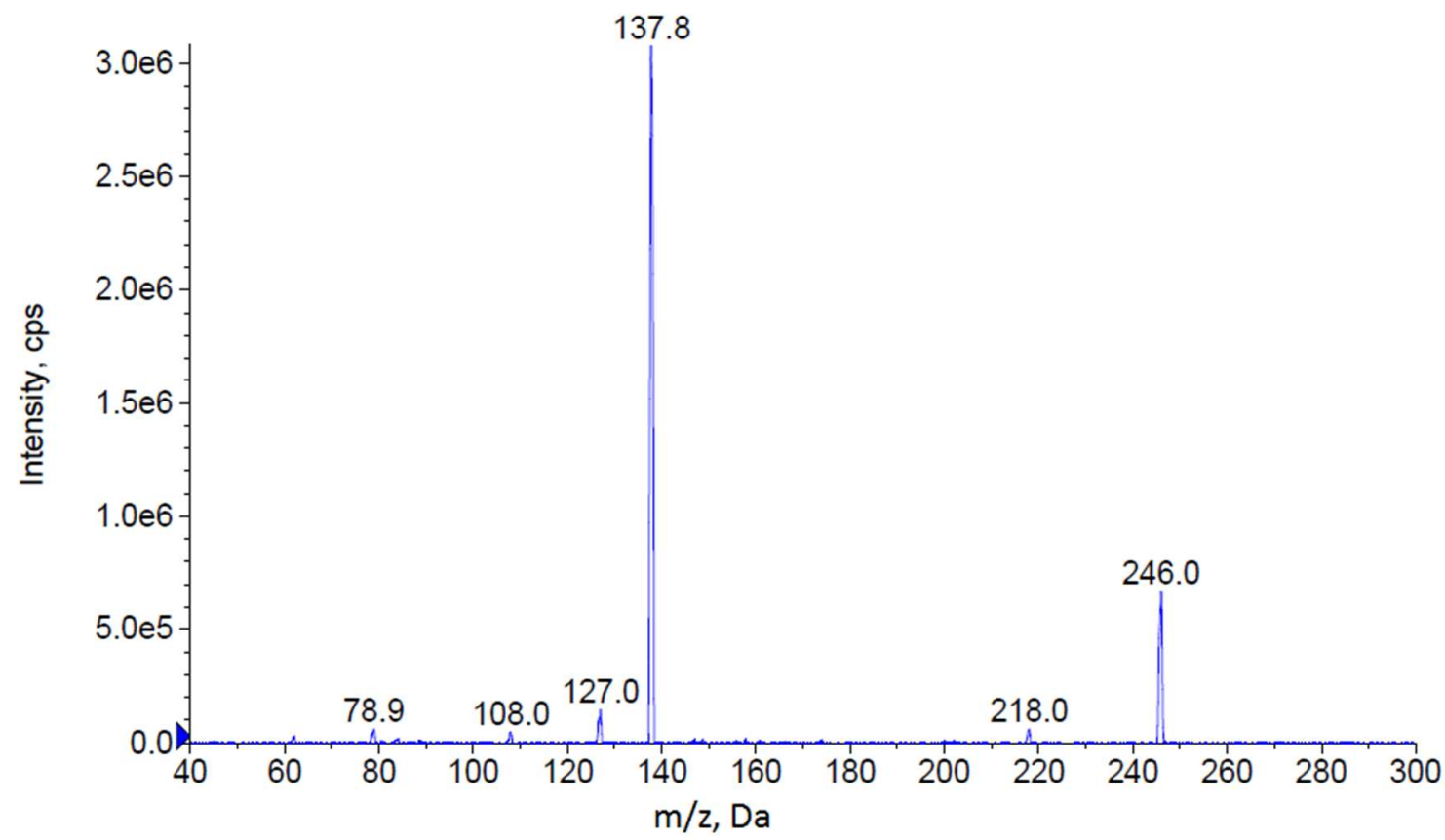

Figure S31: ESI-MS/MS(-) of the compound 5 of $\mathrm{m} / \mathrm{z} 246.0$, from a reaction of 2 with piperidine in EL 


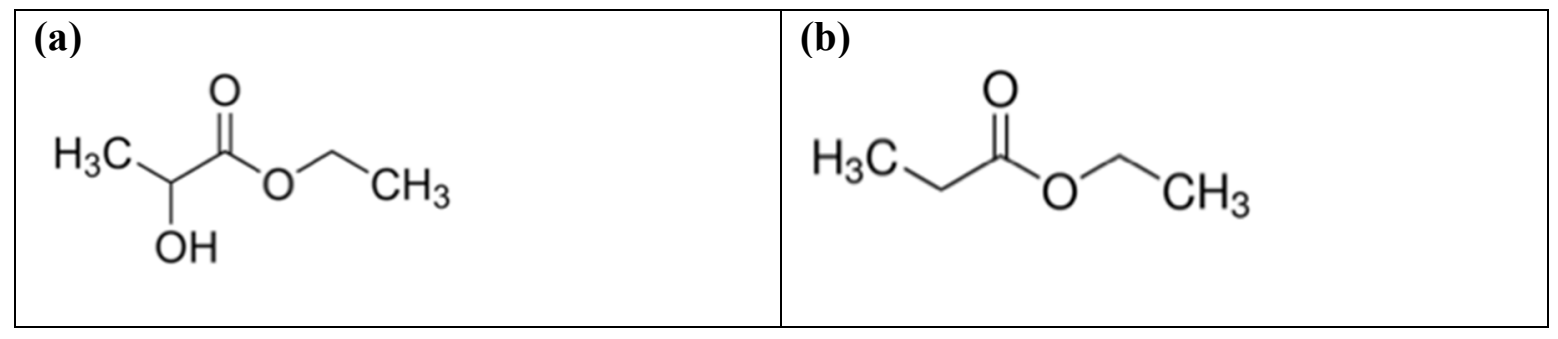

Figure S32: Structure of (a) Ethyl Lactate and (b) Ethyl Propionate

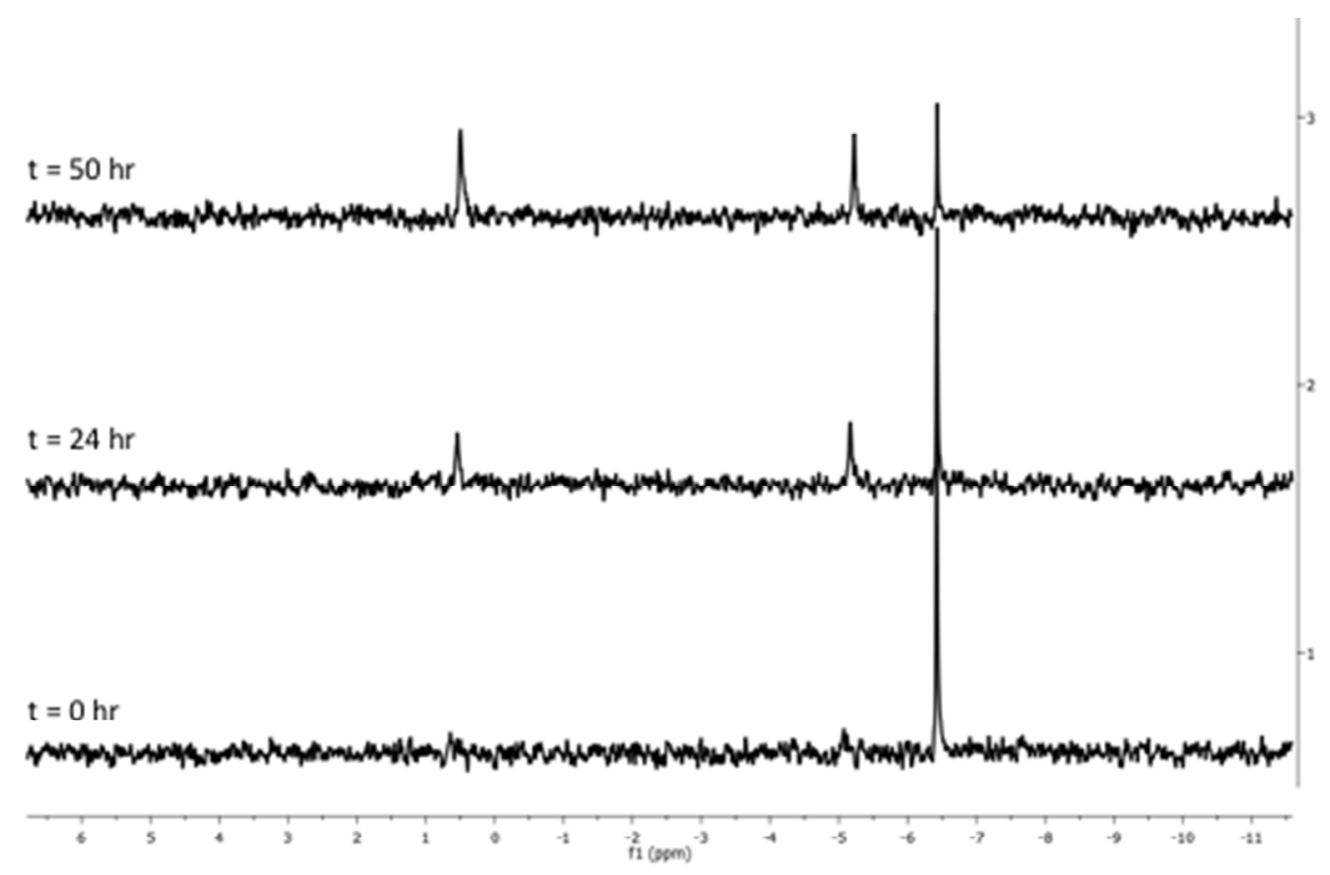

Figure S33: Progressive ${ }^{31} \mathrm{P}$ NMR spectra obtained for the reaction of $\mathbf{2}$ with piperidine in Ethyl Propianate (EP). 
Table S4: Pseudo-first-order rate constants $\left(k_{\text {obsd }}\right)$ for the degradation routes of 2 in several solvents.

\begin{tabular}{|c|c|c|c|}
\hline Solvent & $10^{5} k_{o b s d} \mathrm{~s}^{-1}, \mathrm{~S}_{\mathrm{N}} 2(\mathrm{P})$ & $10^{5} k_{o b s d /} s^{-1}, S_{N} A r$ & $10^{5} k_{o b s d} \mathrm{~s}^{-1}, \mathrm{~S}_{\mathrm{N}} 2(\mathrm{C})$ \\
\hline$[\mathrm{Bmim}] \mathrm{BF}_{4}$ & 2.64 & 2.28 & 7.08 \\
\hline [Bmim]DCA & 4.52 & 2.88 & 6.30 \\
\hline$[\mathrm{Bmim}] \mathrm{NTf}_{2}$ & 0.99 & 1.85 & 3.78 \\
\hline$[\mathrm{Bmim}] \mathrm{PF}_{6}$ & 1.34 & 2.19 & 4.90 \\
\hline$[\mathrm{B} 2 \mathrm{mim}] \mathrm{NTf}_{2}$ & 0.99 & 1.46 & 2.50 \\
\hline$[\mathrm{B} 2 \mathrm{mim}] \mathrm{BF}_{4}$ & 0.82 & 1.00 & 3.01 \\
\hline$[\mathrm{E} 2 \mathrm{mpAm}] \mathrm{NTf}_{2}$ & 0.74 & 0.77 & 1.84 \\
\hline [Bmpyrr]NTf ${ }_{2}$ & 0.49 & 0.73 & 1.50 \\
\hline [Bmpy]DCA & 5.15 & 0.95 & 0.34 \\
\hline [Bmpyrr]DCA & 1.28 & 1.80 & 3.34 \\
\hline CYM & - & 43.5 & 12.5 \\
\hline LYM & - & 117 & 27.9 \\
\hline GLU & 239 & 1110 & 141 \\
\hline 2-MeTHF & 9.33 & 51.0 & 5.50 \\
\hline
\end{tabular}




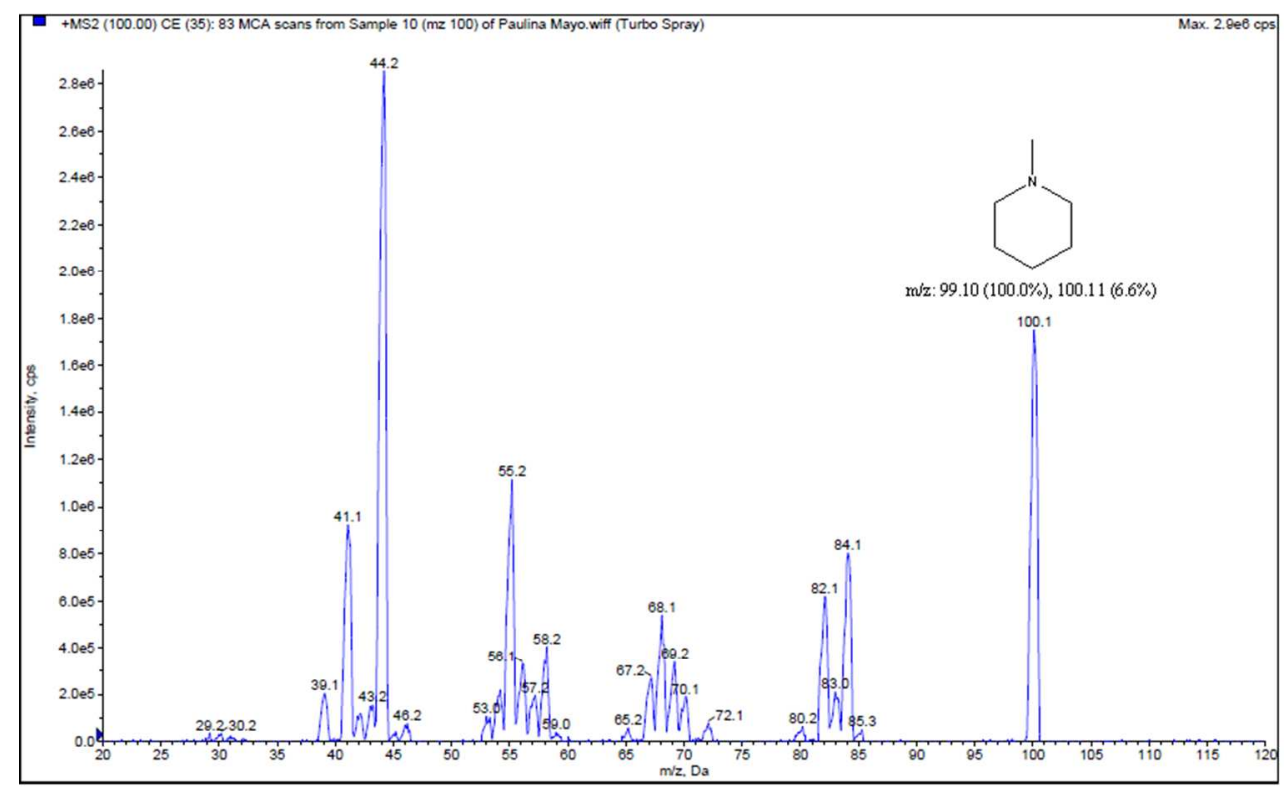

Figure S34: ESI-MS/MS(-) of the compound 5 of $\mathrm{m} / \mathrm{z} 100.1$, from a reaction of 1 with piperidine in $\mathrm{MeCN}$ 